SANDIA REPORT SAND83-0518 • Unlimited Release • UC-92a

Printed July 1983

\title{
Corrosion Response of Downhole Steam- Generator Assembly and Instrumentation and Supply-Line Tubings at Long Beach Field Test
}

\section{Prepared by}

Sandia National Laboratories

Albuquerque, New Mexico 87185 and Livermore, California 94550

for the United States Department of Energy

under Contract DE-AC04-76DP00789

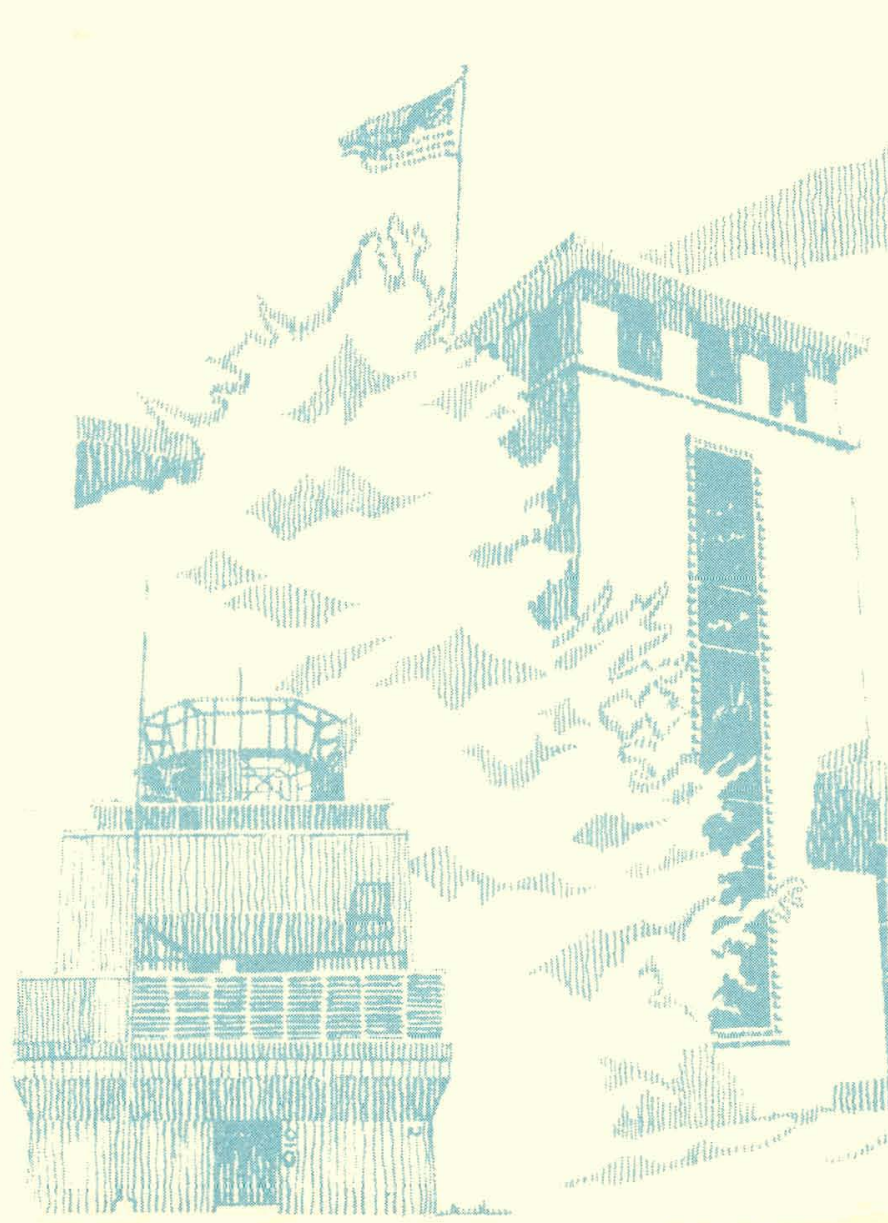




\section{DISCLAIMER}

This report was prepared as an account of work sponsored by an agency of the United States Government. Neither the United States Government nor any agency Thereof, nor any of their employees, makes any warranty, express or implied, or assumes any legal liability or responsibility for the accuracy, completeness, or usefulness of any information, apparatus, product, or process disclosed, or represents that its use would not infringe privately owned rights. Reference herein to any specific commercial product, process, or service by trade name, trademark, manufacturer, or otherwise does not necessarily constitute or imply its endorsement, recommendation, or favoring by the United States Government or any agency thereof. The views and opinions of authors expressed herein do not necessarily state or reflect those of the United States Government or any agency thereof. 


\section{DISCLAIMER}

Portions of this document may be illegible in electronic image products. Images are produced from the best available original document. 


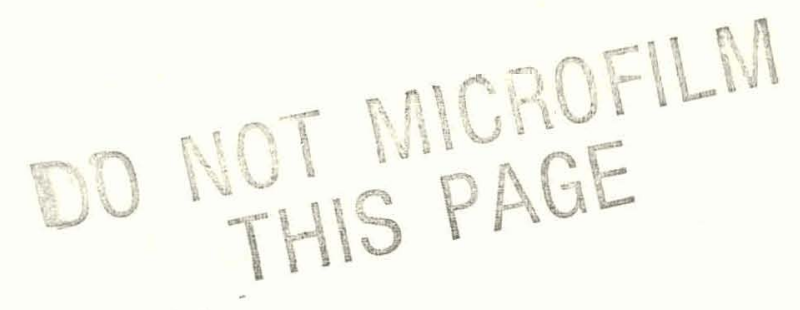

Issued by Sandia National Laboratories, operated for the United States Department of Energy by Sandia Corporation.

NOTICE: This report was prepared as an aceount of work sponsored by an agency of the United States Government. Neither the United States Government nor any agency thereof, nor any of their employees, nor any of their contractors, subcontractors, or their employees, makes any warranty, express or implied, or assumes any legal liability or responsibility for the accuracy, completeness, or usefulness of any information, apparatus, product, or process disclosed, or represents that its use would not infringe privately owned rights. Reference herein to any specific commercial product, process, or service by trade name, trademark, manufacturer, or otherwise, does not necessarily constitute or imply its endorsement, recommendation, or favoring by the United States Government, any agency thereof or any of their contrectors or subcontractors. The views and opinions expressed herein contractors or subcontractors. The views and opinions expressed herein do not necessarily state or reflect those of the United States Government, any
agency thereof or any of their contractors or subcontractors.

Printed in the United States of America Availahle frnm

Avilation

Information Service

U.S. Department of Commerce

5285 Port Royal Road
Springileld, VA 22161

NTIS price codes

Printed copy: A04

Microfiche copy: A01 
Corrosion Response of Downhole Steam-Generator Assembly And Instrumentation And Supply-Line Tubings At Long Beach Field Test*

L. J. Weirick

Sandia National Laboratories**

Albuquerque, New Mexico 87185

\begin{abstract}
Three families of metals were used to make the non-combustor components for Sandia's downhole steam generator assembly and supply and instrumentation lines. These three families were: first, plain carbon steel (API Grade J 55); second, austenitic stainless steels (316 and 310 ); and third, a nickel-base superalloy (Inconel 600). The metals in all three of these families were found to be deficient in their corrosion resporise. J 55 exhibited minimal to severe general corrosion (rusting). The austenitic stainless steels pitted and cracked. Incone1 600 showed both severe pitting and some intergranular attack. For the most part, these materials were found to be unsultable for extended life in a downhole steam generator.

It is recommended that Inconel 625 be used in future systems where a moderate strength material is specified and Inconel 718 be considered where a high-strength material is necessary.
\end{abstract}

*This work supported by the U.S. Department of Energy (DOE), under Contract Number DE-AC04-76-DP00789.

**A U.S. DOE.rFacility. 


\section{DISCLAIMER}

This report was prepared as an account of work sponsored by an agency of the United States Guvernment. Neither the United States Government nor any agency thereof, nor any of their employees, makes any warranty, express or implied, or assumes any legal liability or responsibility for the accuracy, completeness, or usefulness of any information, apparatus, product, or process disclosed, or represents that its use would not infringe privately owned rights. Reference herein to any specific commercial product, process, or service by trade name, trademark, manufacturer, or otherwise does not necessarily constitute or imply its endorsement, recommendation, or favoring by the United States Government or any agency thereof. The views and opinions of authors expressed herein do not necessarily state or reflect those of the United States Government or any agency thereol. 
Corrosion Response of Downhole Steam Generator Assembly And Instrumentation And Supply Line Tubings At Long Beach Field Test*

L. J. Weirick

Sandia Nationa1 Laboratories**

Albuquerque, New Mexico 87185

\section{ABSTRACT}

Three families of metals were used to make the non-combustor components for Sandia's downhole steam generator assembly and supply and instrumentation lines. These three families were: first, plain carbon steel (API Grade J 55); second, austenitic stainless steels ( 316 and 310 ); and third, a nickel-base superalloy (Inconel 600). The metals in all three of these families were found to be deficient in their corrosion response. J 55 exhibited minimal to severe general corrosion (rusting). The austenitic stainless steels pitted and cracked. Inconel 600 showed both severe pitting and some intergranular attack. For the most part, these materials were found to be unsuitable for extended life in a downhole steam generator.

It is recommended that Inconel 625 be used in future systems where a moderate strength material is specifled and Inconel 718 be considered where a high strength materia1 is necessary.

\footnotetext{
*This work supported by the U.S. Department of Energy (DOE), under Contract Number DE-AC04-76-DP007.89.
}

${ }^{* *}$ A U.S. DOE Facility. 
THIS PAGE LEFT BLANK INTENTIONALLY 
TABLE OF CONTENTS

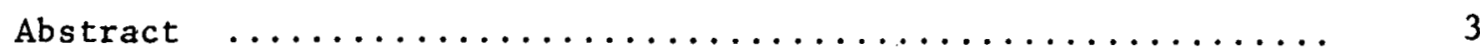

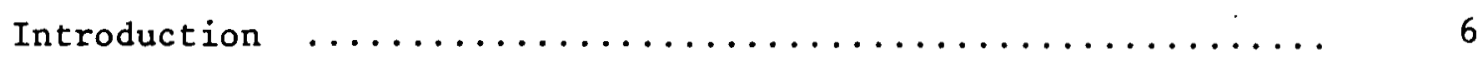

Steam Generator Design $\ldots \ldots \ldots \ldots \ldots \ldots \ldots \ldots \ldots \ldots \ldots \ldots$

Experimental Procedures $\ldots \ldots \ldots \ldots \ldots \ldots \ldots \ldots \ldots \ldots \ldots \ldots$

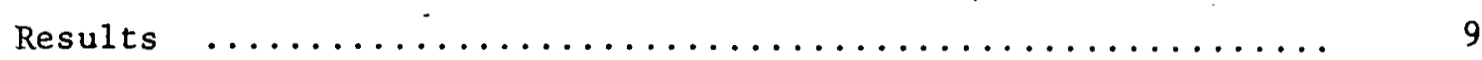

1. Corrosion of 555 Pipes $\ldots \ldots \ldots \ldots \ldots \ldots \ldots \ldots \ldots \ldots \ldots$

2. Corrosion of 316 sS Tubulars $\ldots \ldots \ldots \ldots \ldots \ldots \ldots \ldots \ldots$

3. Thermocouple sheathing $\ldots \ldots \ldots \ldots \ldots \ldots \ldots \ldots \ldots \ldots$

4. Supply Line and Thermocouple Protective Tubing ....... 11

5. Swagelok Nut $\ldots \ldots \ldots \ldots \ldots \ldots \ldots \ldots \ldots \ldots \ldots \ldots \ldots$

6. Corrosion of 310 S.S. Generator Components ......... 14

7. Corrosion of Incone1 600 Tubulars $\ldots \ldots \ldots \ldots \ldots \ldots$

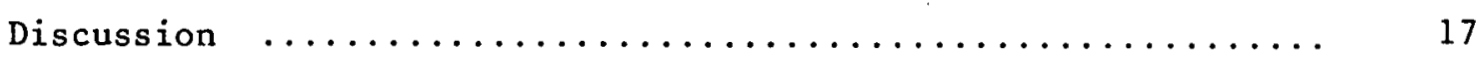

1. Pitting Corrosion $\ldots \ldots \ldots \ldots \ldots \ldots \ldots \ldots \ldots \ldots \ldots \ldots \ldots$

2. Crevice Corrosion $\ldots \ldots \ldots \ldots \ldots \ldots \ldots \ldots \ldots \ldots \ldots \ldots$

3. Intergranular Attack $\ldots \ldots \ldots \ldots \ldots \ldots \ldots \ldots \ldots \ldots \ldots$

4. Stress Corrosion Cracking $\ldots \ldots \ldots \ldots \ldots \ldots \ldots \ldots \ldots$

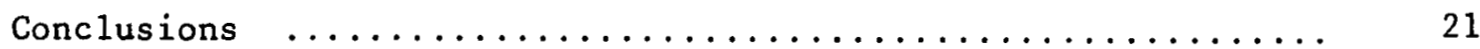

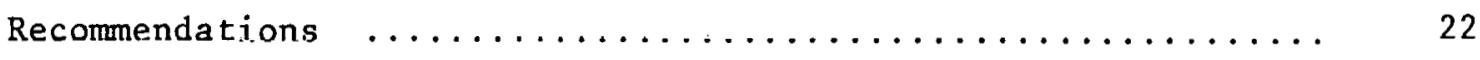

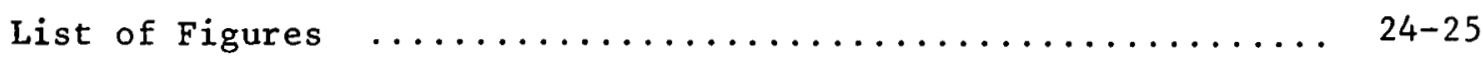

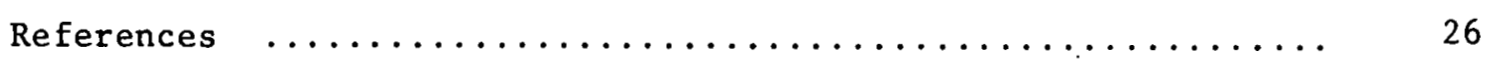

Acknowledgements $\ldots \ldots \ldots \ldots \ldots \ldots \ldots \ldots \ldots \ldots \ldots \ldots \ldots \ldots \ldots$

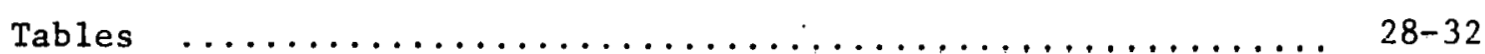

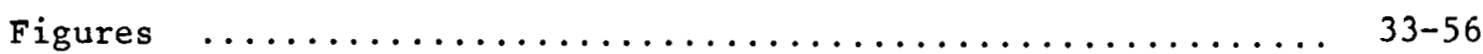




\section{INTRODUCTION}

The goal of the U.S. Department of Energy's Project DEEP STEAM is to develop the technology necessary for economical recovery of heavy oil ( $\left\langle 18^{\circ}\right.$ API) from deep reservoirs ( $>2500$ feet).1 Two approaches are being evaluated: optimizing injection string components for surface generated steam (this approach will not be further discussed within this report) and developing downhole steam generators to deliver the steam at the producing tormation. Sandia National Laboratories entered into an agreement with the city of Long Beach Lu test two generators on wells operated in the Wilmington Field by Long Beach 011 Development Company (LBOD). One of the units burned diesel fuel in oxygen and was surface-operated. The detalls of the design, operation and system performance of this unit are given in a report by J. B. Moreno. 2 The other unit burned diesel fuel in air and was operated downhole. The detalls of the design, operation and system performance of this untt are given in a réport by B. W. Marshal1. 3 Allalyses of the materials performance of the combustors of the two systems is given in two reports.4,5 Analyses of the materlals performance of selected non-combustor materials are reported herein.

The history of the oxygen/diesel steam generator unit is summarized as follows. 2 The steam generator was operated at ground level, with the steam and combustion products delivered to the reservoir through 2022 feet of calciumsilicate Insulated tubing. Typlcally, the combustion efficiency was $95 \%$ and the steam quality was 56\%. Excluding interruptions not attributable to the oxygen/. diesel system, steam was injected $78 \%$ of the time over a four month period. System Iffetime was 1 imited by the combustor, which required some parts replacement every 2-3 weeks. The test was extensively instrumented to provide the required data. Problems with downhole instrumentation, particularly thermocouples, were experienced. 
The history of the air/diesel downhole steam generator (DSG) units is summarized as follows. ${ }^{3}$ Equipment was assembled on site and checked out in the spring of 1981. The first DSG unit was placed in LBOD wel1 SZ1-44 and combustion initiated in June 1981. After a period of operation mixed with periods of inoperation due to surface air compressor problems, loss of cooling water, debris buildup in downhole alr and water filters, and gradual degradation in the downhole steam temperature and pressure measuring devices, the unit was removed from the well in August for inspection. Evidence of combustor overheating and melting (due to the loss of cooling water), filter rupture, and some corrosion resulted in design modifications for a second unit to be placed downhole.

The second unit, with the combustor and steam generator section identical to the first unit, was returned to the site and surface tested in late october. It was placed downhole with no difficulties and combustion initiated on November 15,1981 . Operation continued at an average of about $80 \%$ of the time until the end of February 1982 with the major portion of the down time again due to surface air compressors. Typical operating conditions were: energy output 2 to $4 \mathrm{MMBu} / \mathrm{hr}$; air pressure - 1200 to $1400 \mathrm{psi}$; steam quality - 40 to $50 \%$; and steam temperature $-440^{\circ} \mathrm{F}$.

The unit was removed from the well in March 1982 without incident; all tubing remained banded together and the only significant external corrosion occurred on a carbon steel tailpipe below the generator. However, some internal corrosion and cracking of the stainless steel surfaces that form the combustion chamber was obocrved.

\section{STEAM GENERATOR DESIGN}

A schematic of the air/diesel DSG is shown in Figure 1. This entire section (the'steam generator and combustor) was constructed from 310 stainless steel (SS). 310 SS is a high-alloy composition, austenitic stainless steel noted 
for its high resistance to corrosion and oxidation at high temperatures while maintaining good strength. It also has good weldability and is commercially avallable. Table I lists the chemical composition of 310 SS and Table II gives 1ts mechanical properties.

A schematic of the No. 2 air/diesel system is shown in Figure 2. In addition to the:steam generator, the outer housings for the instrumentation package and filter cans were made from $310 \mathrm{SS}$. The sample, caustic and annulus treatment lines and outer sheathings on the RTD's were made from Inconel 600 tubing in the proximity of the steam generator system. Above the steam generator system, $316^{\circ}$ SS tubing was used. The thermocouple sheathings for the air/diesel generator were made of Inconel 600 while those for the oxygen/diesel well were made of 316 SS. The chemical compositions and mechanical properties are given, respectively, in Tables I and II for Inconel 600 and 316 SS.

The water and air supply lines were API Grade J 55 pipe, which is essentially plain carbon steel (composition and mechanical properties given in Tables $I$ and II, respectively). In addition, the packer body and exhaust pipe were also made from this material.

A summarization of the environments to which the various components of the steam generator system were exposed is given in Table III. As a function of time, the fluid in the annulus was both untreated and treated with oxygen scavengers and film inhibitors. Also, as a function of time and location, the temperature varied between 100 and $\sim 450^{\circ} \mathrm{F}$. For the exhaust pipe (the environment below the packer), the $\mathrm{pH}$ of the generator effluent varied between 2 and 7 depending upon the effectiveness of the caustic injection.

\section{EXPERIMENTAL PROCEDURES}

Standard procedures were used to examine the corroded components. The initial step was to remove pleces of the component to be examined from the bulk, usually by 
cutting. A plece was then taken to the metallographic facility to be mounted in epoxy, polished, and subjected to metallographic examination. Another piece was usually examined and photographed using a macrophotographic camera. A third piece, along with the mounted first piece, was examined in a scanning electron microscope (SEM) and subjected to energy dispersive X-ray analysis (EDX) of various microconstituents in the SEM.

Loose corrosion products were chemically and structurally analyzed using EDX and $x$-ray diffraction equipment, respectively.

\section{RESULTS}

Corrosion of J55 Pipes

There were four major components which utilized a plain carbon steel for construction. Three were J55 pipe; the water supply, air supply and exhaust pipes. The fourth application was the packer body. Three of these components (water supply, air supply and packer) were subjected to the annulus environment. None of these components exhibited anything more than superficial, cosmetic corrosion. Apparently, the additives to the annulus fluid, which were oxygen scavengers and film forming inhibitors, performed extremely well, preventing any significant corrosion. The fourth component was the exhaust pipe which was subjected to the generator effluent. The exhaust pipe was found to be very severely and non-uniformly corroded, indeed, perforated in spots. Analysis of the rust-colored corrosion product found it to be primarily a mixture of hematite $\left(\mathrm{Fe}_{2} \mathrm{O}_{3}\right)$ and hydrated hematite $\left(\mathrm{Fe}_{2} \mathrm{O}_{3} \quad \mathrm{XH}_{2} \mathrm{O}\right)$. There is reason to believe ${ }^{3}$ that the caustic $(\mathrm{NaOH})$ injected to neutralize the very acidic ( $\mathrm{pH}$ of 2) generator effluent was not all reaching the injection point. If the, generator effluent was not buffered substantially towards a $\mathrm{pH}$ of 7 , a plain carbon steel such as the exhaust pipe would corrode significantly at the temperatures and steam and oxygen contents observed. 


\section{Corrosion of 316 SS Tubulars}

As mentioned previously, 316 austenttic stainless steel was used for supply IInes (fuel, caustic, annulus treatment, sample) above the generator system and as sheathing for the thermocouples secured to the insulated tubing in the annulus of the oxygen/diesel well. In addition, some fittings were made from this alloy. Three examples of corrosion induced fallures within this material will be given as representative of this set.

Thermocouple sheathing - The first example of a corrosion induced failure was the fallure of thermocouple sheathings. Examples of cracked sheathing are shown in Figures 3 and 4 . It can be seen that the cracking was not confined to a specific area. Figures 5 and 6 are SEM macrographs of cracks showing more detail on the length and depth of the cracks. An end view of a thermocouple separated in an area of a crack is shown in Figure 7. Indeed, cracking has resulted in fallure of the thermocouples. Figure 8 shows the chemical analysis spectrum obtained from this surface using the EDX technique. The spectrum identifies the material as a 300 series stainless steel (1.e. $\mathrm{Fe}, \mathrm{Cr}, \mathrm{NL}$ peaks) and also shows a very prominent peak for chlorine (indicating the presence of the chloride Ion). Higher magnification views of the fracture surface shown in Figure 7 are shown in Figures 9 and 10. Figure 9 shows that the area of the transition from environmentally caused fracture to that caused by the mechanical separation of the thermocouple (overload) upon bending open for observation. The overload area is seen as ductile-dimple rupture (tup area uf plútograph). The environmentally induced fracture surface (bottom area of photograph) has the appearance of transgranular (across grains) fracture. Figure 10 shows an area adjacent to the cracked area where the surface has been subsequently corroded. Another area of the fracture surface where the subsequent corrosion has completely obscured the underlying fracture surface is shown in Figure 11 . Chemical 
analysis of this corrosion product is shown in the spectrum of Figure 12 . The film is a chromium-rich oxide, probably a $\mathrm{Cr}_{2} \mathrm{O}_{3} \cdot \mathrm{Fe}_{2} \mathrm{O}_{3}$ spinel.

Another technique used to examine the severity and type of cracking is to metallographically cross-section the component of interest. Figure 13 shows the cross-section of a thermocouple sheathing at $100 \mathrm{x}$ in the unetched condition. It can be seen that cracks have initiated on both sides of the thermocouple sheathing. This does not mean that the interior of the thermocouple (chrome1alumel wires and alumina insulation) can generate cracks in the sheathing but rather that the sheathing was breached and solution got inside. The etched macrograph of Figure 14 indicates that the cracking is indeed transgranular. The crack path follows the grain boundaries only when directionally convenient but primarily transverses the grain structure.

These results were obtained for a small diameter (1/16") thermocouple used in the $0 / D$ well. Similar results were observed for two larger diameter (1/8") thermocouples manufactured in a similar manner with the same materials and exposed to the same environment.

An additional set of data was taken on the small thermocouple sheathings. Microhardness traverses were made to check for any material embrittlement due to hardness increase. No hardness increase over the standard values was measured. Thus, a general embrittlement of the material due to an interstitial specles ingress such as hydrogen or oxygen did not occur.

The cause of the cracking was identified as chloride-assisted stress corrosion cracking. This cracking mechanism will be further discussed in the Discussion section of this report. Supply Line and Thermocouple Protective Tubing - The second example of a corrosion induced fallure of a 300 series stainless steel component was the pltting 
and cracking of the supply and instrumentation lines. The former were the $3 / 8^{\prime \prime}$ tubes above the generator system, while $1 / 4^{\prime \prime}$ tubes were used to protect the thermocouples in the vicinity of the air/diesel DSG. Figures 15 and 16 show examples of the pitting of one of the thermocouple protective tubes at various magnifications. Figure 15 in particular reveals the linearity of the pits along the axis of the tubular. This linearity is believed to be associated with the mechanical packaging of the tubes in bundles and suggests that the pitting is occurring at a position on a tubing where another tubing is in proximity. Thus, it is the crevice formed between the two tubes which cuncr lbules slguificantly to the corrosion, and this phenomena has been termed "crevice corrosion". Crevice corrosion will be discussed further in the D1scusstun sectiul.

An SEM micrograph of a pitted area is shown in Figure 17. The feature to be noted in this micrograph is the absence of any appreciable corrosion products within the pits. This event is characteristic of corrosion induced pitting. Figure 18 is a higher magnification SEM micrograph of an area at the edge of a pit. (The edge of the pit is at the right side of the photograph). This micrograph shows the characteristic irregular surface morphology associated with the chemical attack of pitting. This micrograph also shows very distinctively the attack at the grain boundaries on the surface of the tube next to the edge of the pit (left side of photograph). This type of attack has been termed "intergranular attack." Intergranular attack will be discussed further in the Discussion section of this paper. Intergranular attack very of ten is the initiating process for subsequent stress corrosion cracking. And indeed it could be the cause for the cracking observed in these tubes, Figures 19 and 20 . Figure 19 reveals the severity of the pitting and Figure 20 shows that again the stress corrosion cracking path was transgranular. 
Swagelok Nut - The third example of corrosion induced fallure of hardware made from 300 series SS was a cracked Swagelok nut. A macrograph of the fractured nut is shown in Figure 21. This particular fitting was on the caustic line bringing $\mathrm{NaOH}$ to the generator effluent for neutralization. The crack encompassed approximately $270^{\circ}$ of the nut circumference. Also, it was noted that the crack direction changed from circumferential to longitudinal at both ends of the crack. This crack path directional change correlates well with a predicted change in primary tensile stress orientation as the crack propagated and the nut loosened. Figure 22 is a high magnification micrograph taken in the SEM showing significant secondary cracking in the SS adjacent to and parallel with the primary crack. Metallographic cross-sections of this Swagelok nut in the area of the primary crack, Figures 23 and 24 , show the complete penetration of the primary crack across the nut wall, Figure 23, the secondary cracking associated with the primary crack, Figures 23 and 24 , and the transgranular paths of the cracks, Figure 24 .

A SEM macrograph of the primary crack in the Swagelok nut is again shown in Figure 25. Assoclated with the crack is a material deposit. The composition of this deposit was determined by using $X$-ray fluorescent analysis, the results of which are shown in Figure 26. The deposit is sodium hydroxide which this tubular was carrying. Thus, the cracked nut did allow caustic to exit the tubing at this location. What percentage of caustic was lost through this crack and how much remalned in the tubing and was injected into the generator effluent is indeterminate.

I'here are two possible causes of the cracking in this Swagelok nut; chlorideassisted stress corrosion cracking and hot caustic cracking. Type 300 series austenitic stainless steels are subject to stress corrosion cracking in hot concentrated caustic solutions. For this to have happened, of course, the caustic 
would have had to leak from the inner tube by the Swagelok fitting into the nut before the cracking took place. If the nut was loose enough to allow this, there would probably not be sufficlent tensile stress on the nut to cause cracking. However, it is possible that the fitting was defective or assembled incorrectly such that the caustic leaked into-a properly tightened nut, resulting in stress corrosion cracking.

The other possible cause of the cracking was chloride-assisted stress corrosion cracking. Thls cracking phenomena will be discussed further in the Discussions section of this report.

Corrosion of 310 S.S. Generator Components

As mentioned previously in the Steam Generator Vesign section, the entire air/diesel steam generator was constructed from 310 Ss. Some additional components attached below the generator were also made from $310 \mathrm{ss.} \mathrm{Specifical1y,} \mathrm{a.}$ 310 SS outlet plpe from the generator was welded to another 310 sS pipe attached to a temperature measurement chamber and centralizer assembly. The only visual evidence of any problem with any component made from 310 sS was observed in the weld between the two 310 ss pipes. Figure 27 is a macrograph of this weld showing the severe cracklng. It was conjectured that perhaps the weld was not properly done and lacked full penetration. Indeed, Figure 28 shows that this was the case, i.e., the weld did not fully penetrate and close the folnt to the inner surface. However, the lack of full penetration was not the only cause of the cracking, although an important contributor. Figures 29 and 30 show metallographic cross-sections of the weld zone. It can be seen that, although the primary crack is assoclated with the remaining gap, there are numerous other cracks within and just outside the weld zone. Thus, many cracks have initiated and propagated but most 11kely the first, the fastest, the longest and the 
largest was associated with the mechanical gap. A more detalled look at the metal lography and location of the crack paths both within the weld metal and in the adjacent parent metal are shown in Figures 31 and 32 and in Figures 33 and 34, respectively. In both cases, the crack path followed very distinctly the grain boundaries, that is between the grains or intergranular. The cause of the crack is believed to be chloride-assisted stress corrosion cracking analogous to that seen in the 316 SS components but intergranular rather than transgranular. This cracking phenomena will be discussed further in the Discussions section of this report.

Because of the cracks found in the $310 \mathrm{SS}$ pipe associated with the weld zone, the bottom end of the generator was sectioned at six weld joints for examination. Figures 35 through 37 show typical examples of the microstructure and integrity of these six welds. All six welds exhibited full penetrations, no vold formation and an absence of cracking. Further observation of the metallographic mounts containing these weldment specimens uncovered the following surface response. Figure 38 shows an area of the generator surface where significant compositional microsegregation existed in the material. This surface was exposed to the annulus fluid and no deleterious corrosion response was seen. In contrast, Figure 39 shows an area of the generator surface where the microstructure was clean but intergranular attack has initiated. This surface had been exposed to the generator effluent. Intergranular attack can be an initiator of intergranular, stress corrosion cracking but the correlation was not observed in this instance.

The evidence of cracking associated with the weld which did not exhibit full penetration as opposed to no evidence of cracking in welds which had full penetration causes a comparison to be made. Two major differences in these.welds are apparent. First, the lack of full penetration in the cracked weld could have 
resulted in a much higher tensile stress within the weld region than the full penetration welds. Higher tensile stresses mean increased SCC susceptibility. Second, the cracked weld was subjected to the generator effluent. The generator effluent was also shown to have caused intergranular attack on parent materlal. The full penetration welds were exposed to the annulus fluld. Tlie annulus fluid had no noticeable effect upon the 310 ss material. These pieces of evidence suggest that full penetration welds may have increased sensitivity to SCC when exposed to the generatior effluent environment.

Corrosion of Inconel 600 Tubulars

On the first air/diesel DSG assembly, 300 series sS tubing was used for the entire length of the supply and instrumentation lines. Stress corrosion cracking was encountered in the annulus environment in the vicinity of the steam generator. Thus, on the second air/diesel unit, Inconel 600 tubing was used for the supply and instrumentation lines in the zone containing the generator. This substitution of material did eliminate the stress corrosion cracklug problem. Unfortunately, another problem arose which led to similar results as before, that is, leaky tubes. This time the tubes pitted severely, producing holes, as seen in Figures 40 and 41 . Figure 42 is an $X$-ray fluorescent dnalysis opectrum ohowing the compositional pattern for Inconel 600. A SEM micrograph of a pitted area in an Inconel 600 tube is shown in Figure 43. The lack of corrosion product within the depression is characteristic of pitting. Figure 44 shows a smaller pit but at higher magnification. Contributing to the pit formation was the intergranular attack which undermined the grains, allowing them to detach from the surface. The susceptibility of this material to intergranular attack is further shown in Figure 45. The phenomenon of pitting will be further discussed in the Discussion section of this report. 


\section{DISCUSSION}

With the exception of the general attack of the exhaust pipe by the effluent gases, the failures documented in the Results section of this paper were caused by "localized corrosion". Localized corrosion can be defined as selective removal of metal by corrosion at small spectal areas or zones on a metal surface in contact with a liquid environment. 6 It usually occurs under conditions where the largest part of the original surface either is not attacked or is attacked to a much smaller degree than at the local sites.

\section{Pitting Corrosion}

One common form of localized corrosion is pitting, in which small volumes of metal are removed by corrosion from certain areas on the surface to produce craters or pits. While the shapes of pits vary widely, they usually are roughly saucer shaped, conical or hemispherical.6 Pit walls usually are irregular when viewed under a microscope.

Pitting usually occurs on metals that are covered with a very thin, often invisible, adherent protective surface film which may be formed during fabrication or be produced by reaction with the environment. Pits develop at weak spots in the surface film and at sites when the film is damaged mechanically under conditions where self repair will not occur.

The practical importance of pitting depends on the thickness of the metal and on the penetration rate, which usually decreases with time. The rate of penetration generally decreases if the number of pits increases. The reason for this is that adjacent pits have to share the available adjacent cathode area, which controls the corrosion current that can flow. Most cases of pitting are believed to be caused by local cathode sites in an otherwise normal surface. 
Since pitting is electrochemical, it can be stopped by cathodic protection. 7 It can be prevented also by the use of inhibitors which alter the electrode reactions of the local cell or by coating the surface of the metal with a sacrificial layer or a protective coating.

\section{Crevice Corrosion}

A specific type of pitting corrosion which occurs in crevices is called "crevice corrosion". 6 Crevice corrosion occurs in cracks or crevices formed between mating surfaces of metal assemblies and usually takes the form of pitting or etched patches. Both surfaces may be of the same metal or of dissimilar metals or one surface may be a non-metal. It can occur also under loose fitting washers and gaskets that do not prevent the entry of liquid between them and the metal surface.

Crevice corrosion is believed to initiate as the result of a differential aeration mechanism.' Oxygen in the liquid deep in the crevice is consumed by reaction with the metal. The oxygen content of the liquid at the mouth of the crevice exposed to air, or of bulk liquid in the case of 1mmersion, is greater so a local cell develops in which the anode, or area being attacked, is the surface in contact with the oxygen-depleted liquid. It is also thought that subsequent $\mathrm{pH}$ changes at anode and cathodic sites further stimulate local cell action as in the case of pitting corrosion.

\section{Intergranular Attack}

Intergranular corrosion is a form of localized surface attack in which corrosion occurs preferentially along the grain boundaries of a metal.6 It Initiates on the surface and proceeds by local cell action in the immediate vicinity of a grain boundary. The driving force is a difference in corrosion potential that develops between a thin grain boundary zone and the bulk of the immediate adjacent grains. The difference in potential is often caused by a 
difference in chemical composition between the two zones. The grain boundaries may even contain precipitate particles which usually have a different corrosion potential than that of the grains, which causes a local cell to form. If the precipitate is anodic to the denuded zone it corrodes preferentially and if it is present in a continuous network throughout the grain boundary, it is removed to produce a thin channel, fissure, or crack between adjacent grains. If the precipitate is cathodic to the denuded zone, it remains intact and local cell action develops a crack in the adjacent denuded zone.

Since most 1ntergranular corrosion is the result of small differences in composition at grain boundaries, the metallurgical history of an alloy can be as important as its average chemical composition. In particular, stainless steels are susceptible to intergranular corrosion when improperly heat treated, that is, "sensitized" (chromium carbide precipitates within the grain boundaries).

Intergranular corrosion is often prevented by ensuring a metal microstructure that is immune to this type of attack. For stalnless steels this translates to not heat treating or subjecting the alloy to a use temperature which is within its temperature zone for sensitization, i.e. - carbide formation. $\underline{\text { Stress Corrosion Cracking }}$

"Stress corrosion cracking" is defined as the spontaneous cracking of metals as the result of the combined action of a corrosive environment and tensile stresses, either applied or residual.8 How much stress and how extensive must the corrosive action be to produce cracking? From extensive laburalury work, 8 it is believed that at least in the region where the cracks originate, the stresses must be above the yield strength of the material; that is, the stress must produce some plastic deformation of the material in the 
region where cracking occurs. The tensile stress necessary to produce the plastic deformation is a combination of residual and applied stresses.

Stress corrosion can occur under very mildly corrosive conditions. The new surfaces resulting from a stress-corrosion crack may show evidence of corrosion but other surfaces of the metal usually do not appear to be corroded. If there is severe general corrosion, stress corrosion cracking usually will not occur. Again, stress corrosion cracking occurs in metals exposed in an environment where, if the stresses were lower, there would be no damage. On the other hand, if the metal, subjected to the higher stresses, were in a different environment, there would be no failure.

Stress corrosion cracks in early stages of their development are microscopic. In many cases they are not evident on the exposed surface by normal visual examination and require special techniques such as scanning electron microscopy. As the cracking penetrates further into the material it eventually reduces the supporting cross section to the point where the structure fails from overload.

Stress corrosion cracks arè designaced as two lypes. IHLetciystallitie ur intergranular cracks follow the grain boundaries in the metal. Transcrystalline or transgranular cracks generally pass through the metallic grains rather than follow their boundaries. Transgranular cracking (TG SCC) in austenitic stainless steel is usually associated with chloride-containing aqueous environments. However, under certain metallurgical and/or environmental conditions, the fracture mode may be predominantly intergranular (IG SCC). The occurrence of intergranular cracking is usually associated with the presence of a sensitized microstructure, but not always. 9 
For austenitic stainless steels, there is general agreement, that if stress cracking w111 develop in 304 SS exposed in a given environment, a 316 or 316L SS probably will not be more resistant. Moreover, a higher alloy stainless steel such as 310 SS also will fail in this environment, but after a longer exposure period. 8

Various schemes have been tried in an attempt at preventing stress corrosion cracking of austenitic stainless steels in contact with chlorides, most unsuccessfully. If possible, such as in a closed system, keeping the chloride and oxygen contents of the water to less than 1 ppm may be successful. Another approach is to keep the applied stresses as low as possible, but of course with the uncertainty of the magnitude of the residual stresses (the usual case), this is a risky approach.

\section{CONCLUSIONS}

1. Plain carbon steels can be used for steam generator components when the environment is comparable to the treated annulus water.

2. Some austenitic stainless steels $(304,316,316 \mathrm{~L})$ cannot be used for steam generator components because they undergo transgranular stress corrosion cracking, even in treated water, due to the presence of the chlor1de 1on.

3. Type 310 austenitic stainless steel is more resistant to transgranular stress corrosion cracking than other austenitic stainless steels but is susceptible to Intergranular stress corrosion cracking when sensitized such as when welded.

4. Inconel 600 can be used to avoid stress corrosion cracking in chloride environments, however, it does exhibit severe pitting and intergranular attack. 


\section{RECOMMENDATIONS}

It is recommended that Inconel 625 be used in future systems where a moderate strength material is required and Inconel 718 be considered when a high strength material is necessary.

Inconel 625 is used for 1ts high strength, excellent fabricability (Including joiring), and outstanding corrosion resistance from cryogenic temperatures to $2000^{\circ} \mathrm{F}$. Composition is shown in Table IV and its mechanical properties are shown in Table V. 10

Strength of Inconel 625 is derived from the stiffening effect of molybdenum and columbium on its nickel-chromium matrix. Thus, it is a solid-solution matrix-stiffened face-centered-cubic alloy that does not require precipitationhardening treatments to obtain strength. It is also stable when exposed for extended periods in "sensitization" temperature zones, 1000 to $1800^{\circ} \mathrm{F}$. Inconel 625 is readily fabricated by common industrial practices. Two companion weldIng products 10 ensure achievement of high-quality joints with strength and corrosion resistance comparable to those of the base material.

The high alloy content of Inconel 625 enables it to withstand a wide variety of severe corrosive environments. In mild environments such as the atmosphere, fresh and sea water, neutral salts, and alkaline media there is almost no attack.

In more severe corrosive environments the combination of nickel and chromium provides resistance to oxidizing chemicals, whereas the high nickel and molybdenum contents supply resistance to nonoxidizing environments. The high molybdenum content also makes this alloy very resistant to pitting and crevice corrosion, and columbium acts to stabilize the alloy against sensitization during welding, thereby preventing subsequent intergranular cracking. Also, the high nickel content provides freedom from chloride-ion stress corrosion cracking. 
Inconel 718 is a high-strength, corrosion-resistant material used at -423 to $1300^{\circ} \mathrm{F}$. Composition is shown in Table IV and Its mechanical properties are shown in Table v.11 Inconel 718 can be readily fabricated, even into complex parts. Its welding characteristics, especially its resistance to postweld cracking, are good.

Inconel 718 is an age-hardenable austenitic materlal. Strength is largely dependent on the precipitation of a gamma prime phase following heat treatments. It has good tensile, fatigue, creep, and rupture strength. A major part of the development effort with this alloy was concerned with establishment of the proper heat treatments for producing optimum properties.

Inconel 718 has excellent corrosion resistance to many media. Nickel contributes to a resistance to corrosion by many inorganic and organic (other than strongly oxidizing) compounds throughout wide ranges of acidity and alkalinity. It also is useful in combating chloride-ion stress corrosion cracking. Chromium imparts an ability to withstand attack by oxidizing media and sulfur compounds. Molybdenum is known to contribute to resistance to pitting in many media. 


\section{FIGURES}

1. Schematic of Air/Diesel Downhole Steam Generator

2. Schematic of Air/Diesel Downhole Conflguration

3. Macrograph of Thermocouple Sheathing - 316 SS

4. Macrograph of Thermocouple Sheathing - 316 SS

5. SEM of Cracked Thermocouple Sheathing - 316 SS - Top View $45 X$

6. SEM of Cracked Thermocouple Sheathing - 316 SS - Side View $75 \mathrm{X}$

7. SEM of Cracked Thermocouple Sheathing - 316 SS - End View $45 X$

8. X-Ray Fluorescent Analysis - 316 Stainless Steel (Chloride)

9. SEM of Thermocouple Fracture Surface - 316 SS - Cracked to Overload 1000X

10. SEM of Thermocouple Fracture Surface - 316 SS - Corroded to Cracked 1000X

11. SEM of Thermocouple Fracture Surface - 316 SS - Corroded 1000X

12. X-Ray Fluorescent Analysis of Corrosion Product on Thermocouple Fracture Surface - Chrome - Rich Oxide

13. Metallographic Cross-Section of Thermocouple Sheathing - 316 SS - Unetched 100X

14. Metallographic Cross-Section of Thermocouple Sheathing - 316 ss - Etched $320 \mathrm{X}$

1.5. Macrograph of 316 Sțainless Steel Tubing - Linear Pitting

16. Macrograph of 316 Stainless Steel Tubing

17. SEM of Pit in 316 SS Tubing - 50X

18. SEM of Intergranular Attack and Pitting in 316 SS Tubing - $750 \mathrm{X}$

19. Metallographic Cross-Section of Pit in 316 SS Tubing - Etched $63 \mathrm{X}$

20. Metallographic Cross-Section of Pit in 316 SS Tubing - Etched 100X

21. Macrograph of 316 SS Swagelok Nut - Caustic Line

22. SEM of Secondary Cracking at Edge of Primary Crack $1000 X-316$ SS Swagelok Nut

23. Metallographic Cross-Section of 316 SS Swagelok Nut at Primary Crack-Etched $30 \mathrm{X}$.

24. Metallography of Secondary Crack in 316 SS Swagelok Nut

25. SEM of Primary Crack in 316 SS Swagelok Nut with Material Deposit 35X 
26. X-Ray Fluorescent Analysis of Material Deposit on 316 SS Swagelok Nut

27. Macrograph of 310 SS to 310 SS Weld in Air/Diesel DSG Outlet Pipe

28. Metallographic Cross-Section of Weld Zone in 310 sS Outlet Pipe - Lack of Weld Penetration $9 \mathrm{X}$

29. Metallographic Cross-Section of Weld Zone in 310 sS Outlet Pipe - Cracked 9X

30. Metallographic Cross-Section of Weld Zone in 310 ss Outlet Pipe - Cracked 9X

31. Metallography of Weld Metal in 310 ss Outlet Pipe 25X

32. Intergranular Crack Path in 310 sS We1d Metal 100x

33. Metallography of Parent Meta1 in 310 SS Outlet Pipe 25X

34. Intergranular Crack Path in 310 ss Parent Metal 100X

35. We1d Jolnt at Bottom End of 310 SS Air/Diesel Generator $31 x$

36. Weld Joint at Bottom End of 310 sS Air/Diesel Generator 100X

37. Weld Joint at Bottom End of 310 SS Air/Diesel Generator

38. Surface of 310 SS Generator Showing Microsegregation 100X

39. Surface of 310 SS Generator Showing Intergranular Attack $100 \mathrm{X}$

40. Macrograph of Inconel 600 Tubing - Sample Line for Air/Diesel DSG - Hole

41. Macrograph of Inconel 600 Tubing - Annulus Treatment Line for Air/Diesel DSG - Deep Pit

42. X-Ray Fluorescent Analysis of Incone1 600 Tubing

43. SEM of Pit in Incone1 600 Tubing - 30X

44. SEM of Pit Showing Intergranular Attack on Inconel 600 Tubing - 100X

45. SEM of Intergranular Attack on Inconel 600 Tubing - 400X 


\section{REFERENCES}

1. Management plan for enhanced ofl recovery, ERDA 77-1511, Energy Research and Development Administration, February 1977.

2. J. B. Moreno; "Field Test of Two High Pressure, Direct Contact Downhole Steam Generators, Volume II: Oxygen/Diesel System" SAND83-0145/2, Sand1a National Laboratories, Albuquerque, NM.

3. B. W. Marsha11, "Field Test of Two High Pressure, Direct Contact Downhole Etcam Coneratoro, Volume I: Alr/Diesel System", SANn83-0145/1, Sandia National Laboratories, Albuquerque, NM.

4. F. S. Pettit and G. H. Meier, "Report Covering Examination of Parts From Downhole Steam Generators", SAND83-7016, Sandia National Laboratories, Albuquerque, NM.

5. L. J. Weirick, "Analysis of Combuster Material Failures in Downhole Steam Generators", to be published.

6. H. P. Godard, "Localized Corrosion", NACE Basic Corrosion Course, National Association of Corrosion Engineers, Houston, Texas, December, 1973.

7. A. W. Peabody, "Principles of Cathodic Mrotection", NACE Basicic Corrosion Course, National Association of Corrosion Engineers, Houston, Texas, December, 1973.

8. H. L. Logan, "Stress Corrosion", NACE Basic Corrosion Course, Nationa1 Association of Corrosion Engineers, Houston, Texas, December, 1973.

9. C. Cragnolino and P. P. MacDonald, "Intergranular Stress Corrosion Cracking of Austenitic Stainless Steel of Temperatures Below 100C - A Review", Corrosion Vol. 38, No. 8, August, 1982 .

10. Huntington Alloys, Inc., Inconel Alloy 625, International Nickel Company, Huntington Alloys, Inc., Huntington, WV, 1978.

11. Huntington Alloys, Inc., Inconel Alloy 718, International Nickel Company, Huntington Alloys, Inc., Huntington, WV, 1978. 


\section{ACKNOWLEDGMENTS}

The author wishes to acknowledge the support of the following people:

C. J. Greenholt, 1841, for assistance with the macrophotography

H. Thompson, 1822, for assistance with the metallography.

M. M. Sturm, 1822, for assistance with the scanning electron microscopy. 
TABLE I

METAL COMPOSITIONS

$\begin{array}{cccccc}\text { Designation } & \text { Chromium } & \text { Nicke1 } & \text { Molybdenum } & \text { Carbon } & \begin{array}{c}\text { Iron } \\ \text { J-55 }\end{array} \\ 316 \mathrm{SS} & 17 & 12 & 0.15 & 0.40 & \text { balance } \\ 31033 & 25 & 20 & 2 & 0.08 & \text { balance } \\ \text { Incone1 } 600 & 15 & 72 & - & 0.25 & \text { balance }\end{array}$


TABLE II

$\underline{\text { MECHANICAL PROPERTIES }}{ }^{+}$

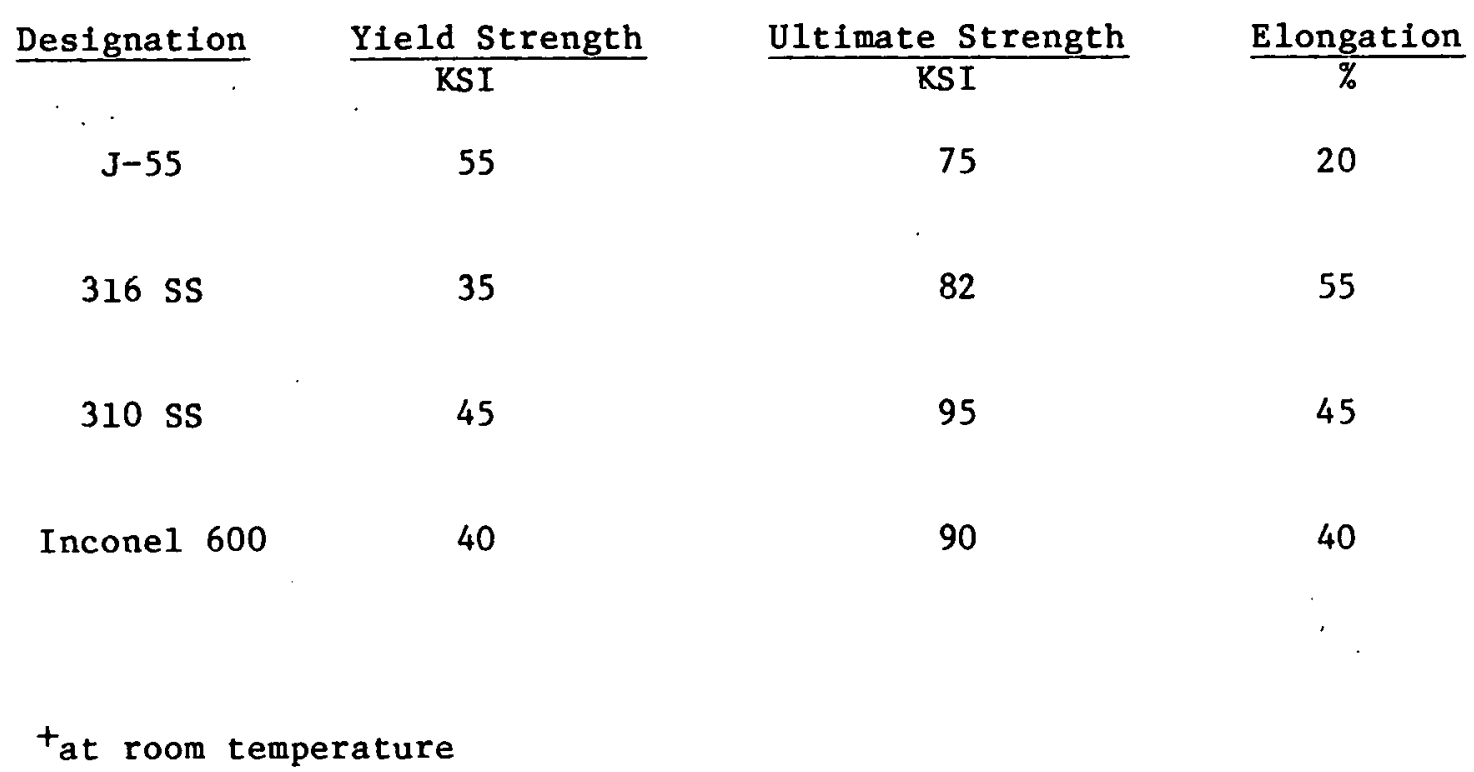


TABLE III

\section{ENVIRONMENTS}

Annulus:

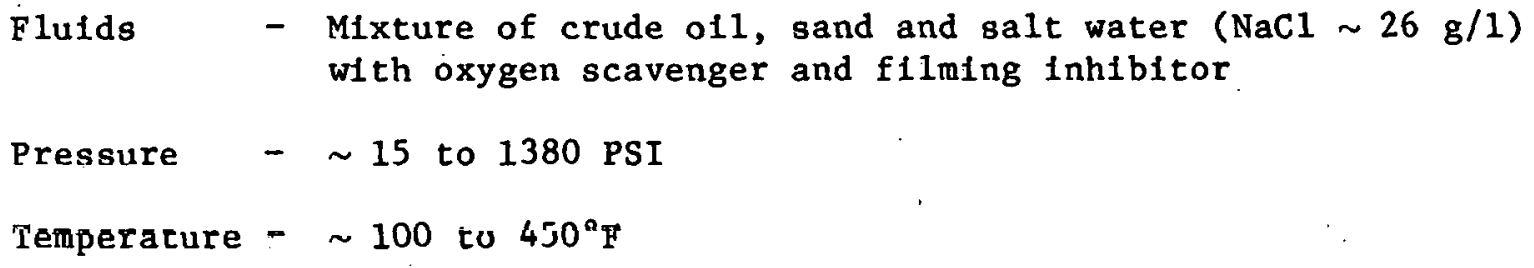

Below Packer:

Generator Effluent $-\mathrm{N}_{2}, \mathrm{CO}_{2}, \mathrm{CO}, \mathrm{O}_{2}, \mathrm{H}_{2}, \mathrm{CH}_{4}, \mathrm{C}_{2} \mathrm{H}_{6}, \mathrm{NO}_{x}, \mathrm{SO}_{x}, \mathrm{H}_{2} \mathrm{~S}$ and $\mathrm{H}_{2} \mathrm{O}$

Caustic (NaOH) - $50 \%$ Aqueous Solution

Pressure $\quad-\sim 1200$ to 1380 PSI

Temperature $\quad-\sim 440$ to $550^{\circ} \mathrm{F}$ 
TABLE IV

\section{COMPOSITIONS OF RECOMMENDED ALLOYS}

$\begin{array}{lcccccc}\text { Designation } & \text { Chromium } & \text { Nickel } & \text { Molybdenum } & \text { Iron } & \text { Nb+Ta } & \text { A1+T1 } \\ \text { Incone1 625 } & 21.5 & 61.0 & 9.0 & 2.5 & 3.6 & 0.4 \\ \text { Inconel } 718 & 19.0 & 52.5 & 3.0 & 18.5 & 5.1 & 1.4\end{array}$


MECHANICAL PROPERTIES OF RECOMMENDED ALLOYS

\begin{tabular}{|c|c|c|c|c|}
\hline Designation : & Yleld & $\frac{\text { Strength }}{\mathrm{KSI}}$ & $\frac{\text { U1timate Strength }}{\mathrm{KSI}}$ & $\frac{\text { Elongation }}{\%}$ \\
\hline Inconel 625 & & 55 & 120 & 45 \\
\hline 7 & $\because x$ & 161 & 190 & 20 \\
\hline
\end{tabular}




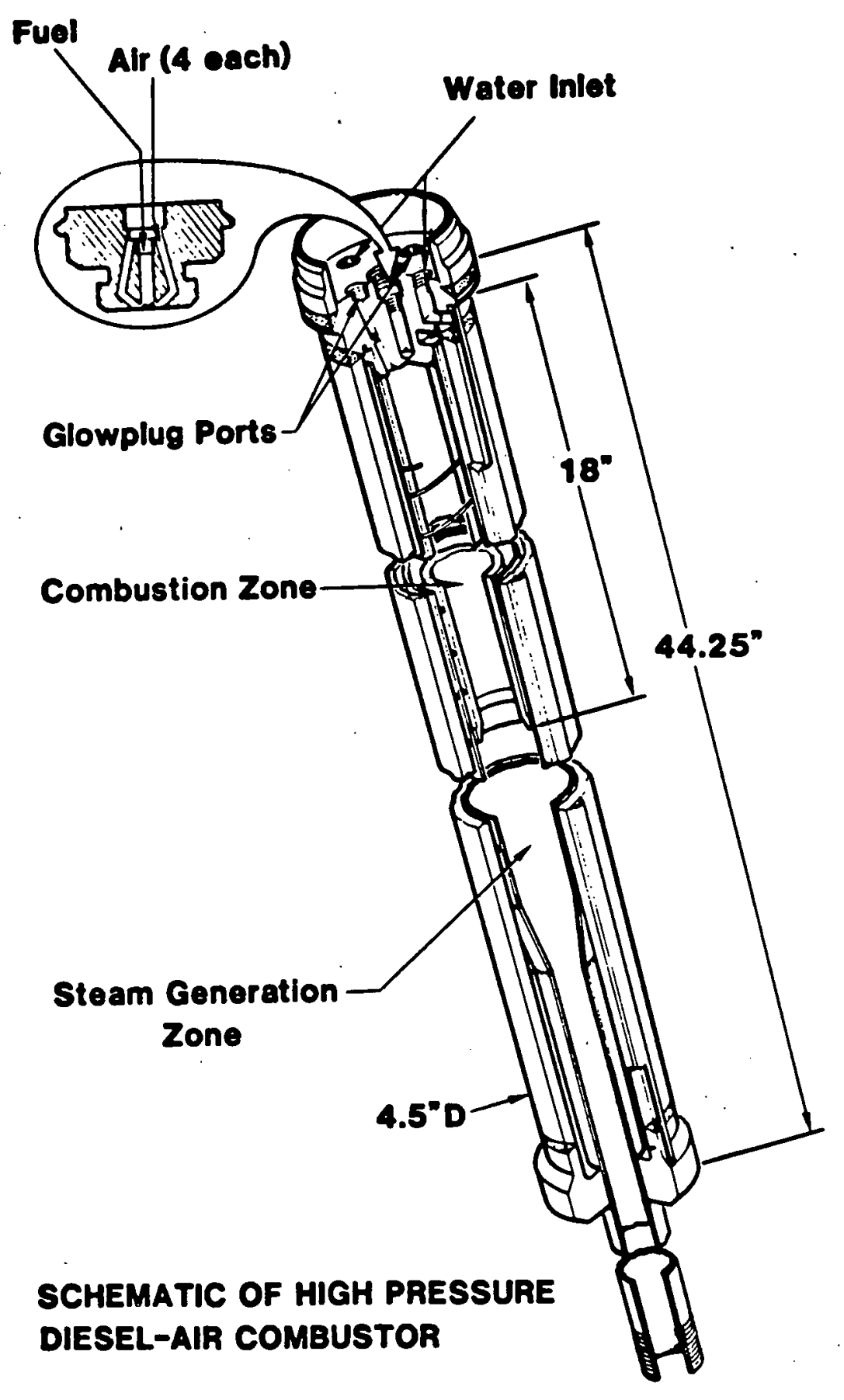

Figure 1. Schematic of Air/Diesel Downhole Steam Generator 


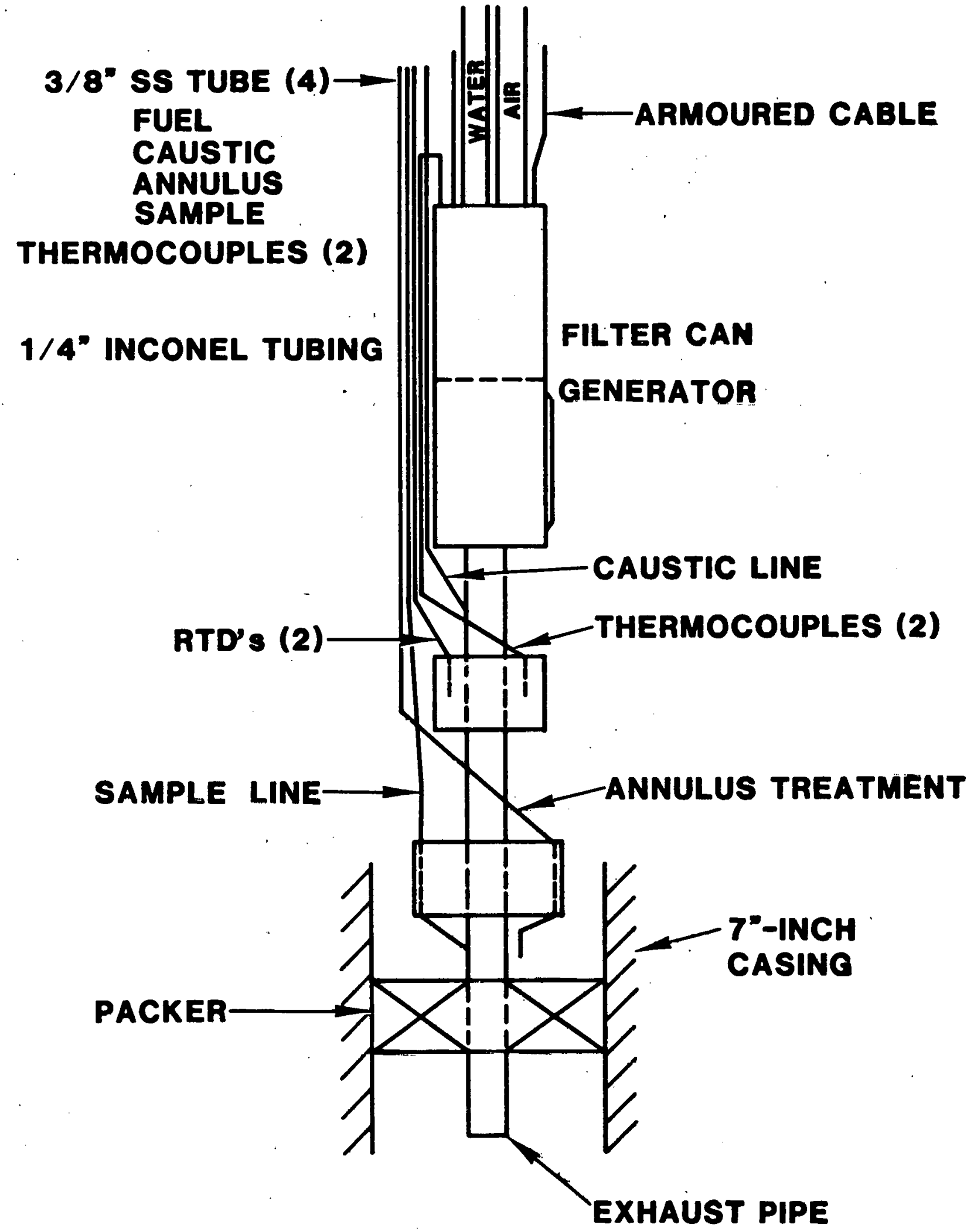

Figure 2. Schematic of Air/Diese1 Downhole Configuration 


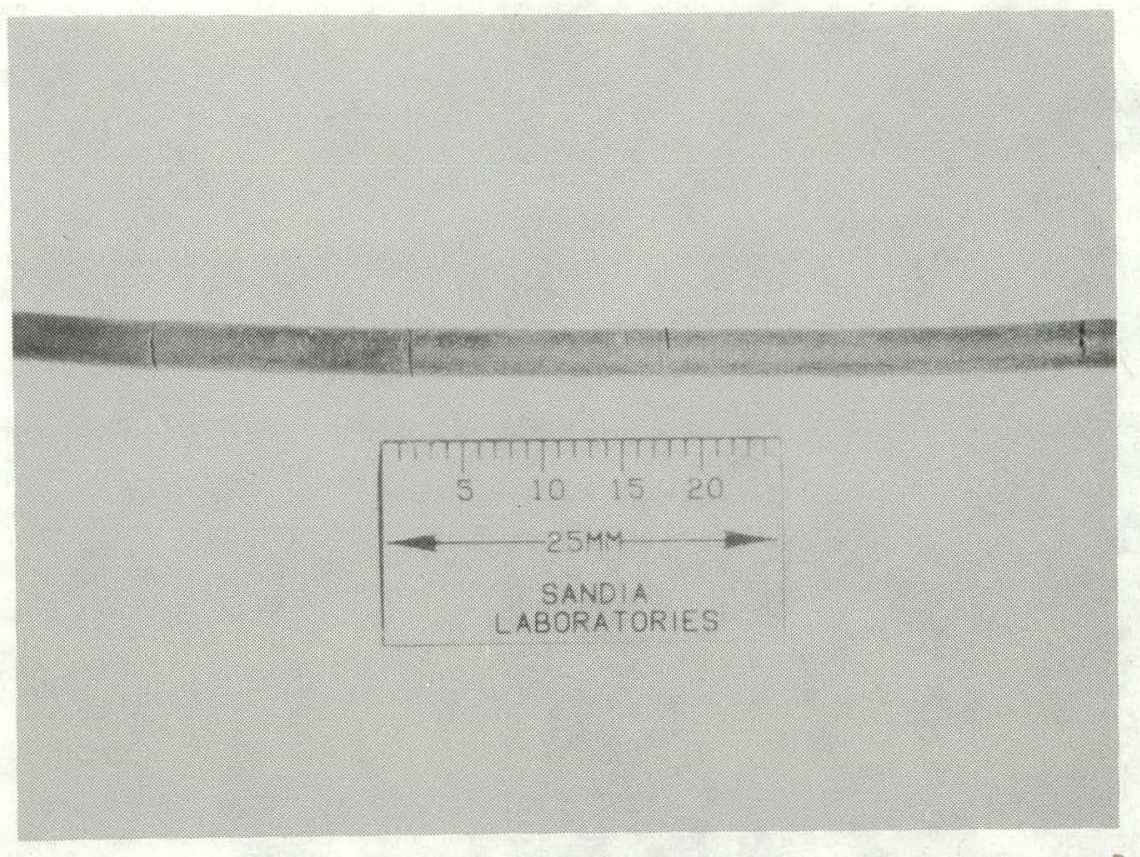

Figure 3. Macrograph of Thermocouple Sheathing.-316 SS

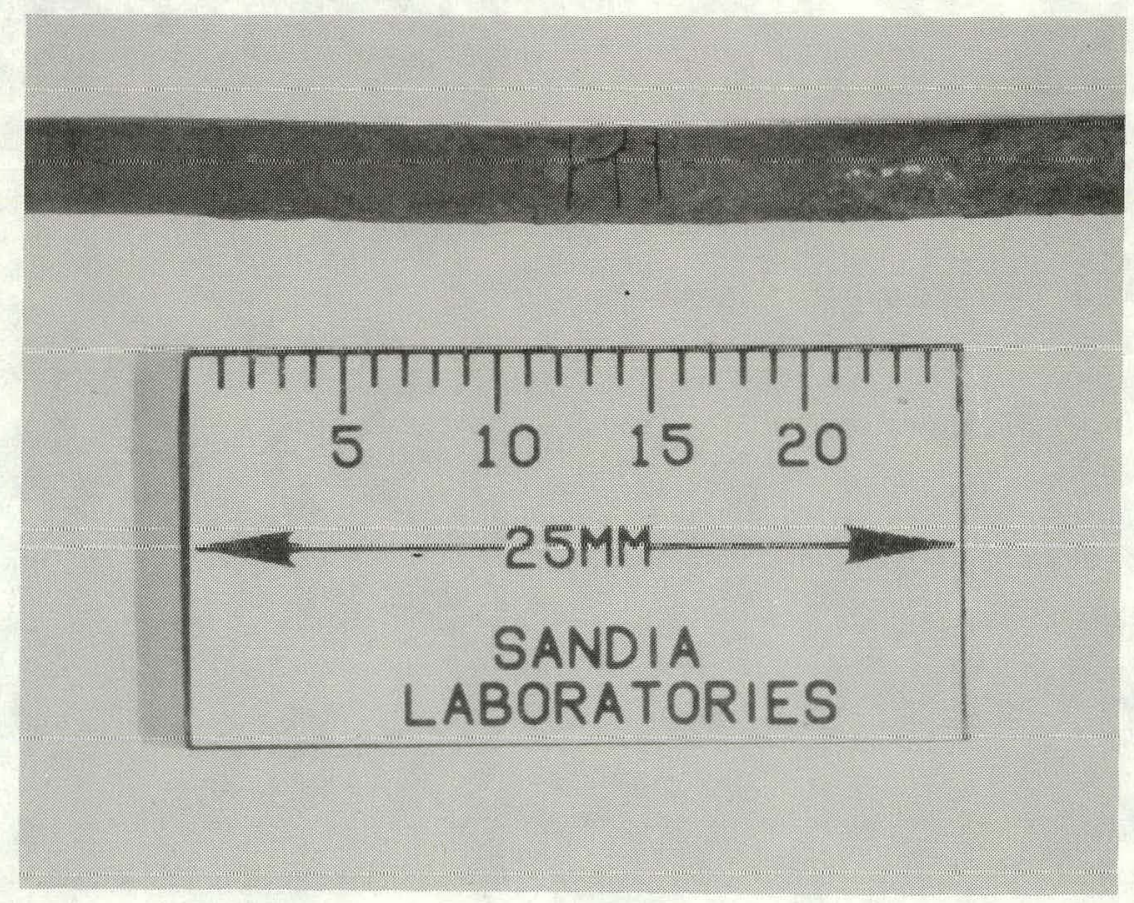

Figure 4. Macrograph of Thermocouple Sheathing - 316 SS 


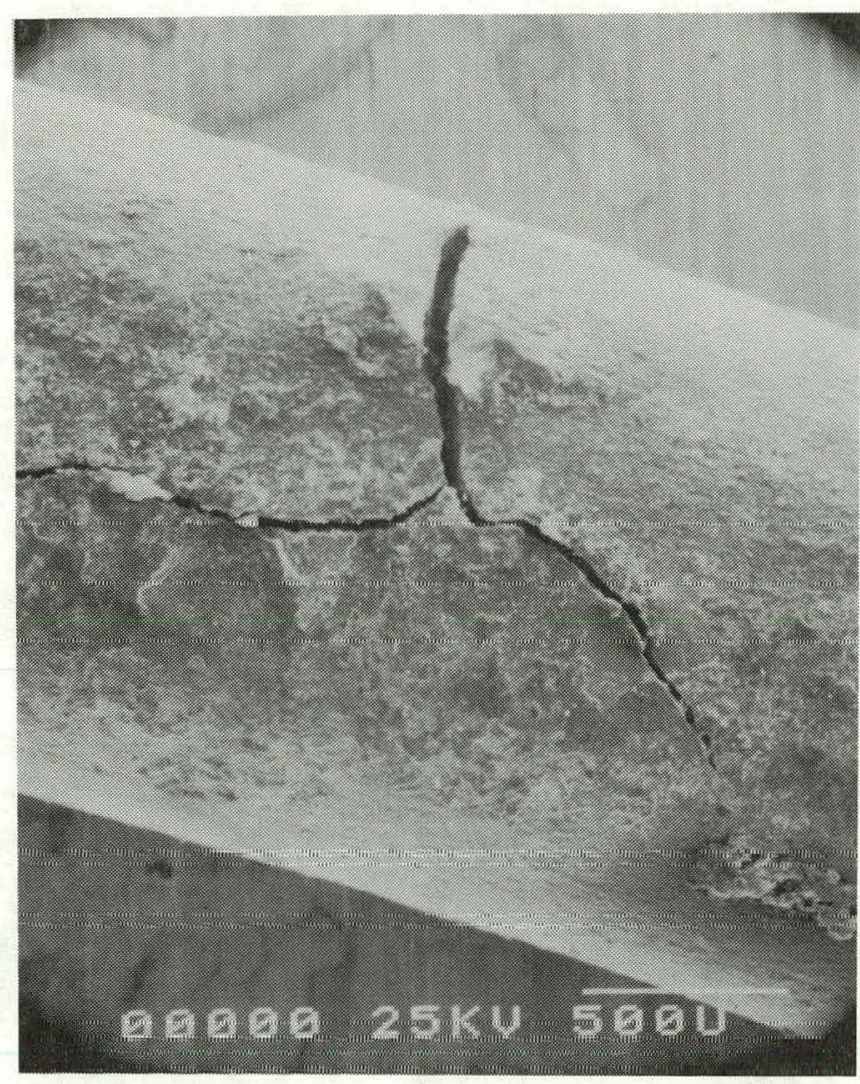

Figure 5.

SEM Cracked Thermocouple Sheathing
316 SS
- Top View $45 X$

Figure 6.

SEM Cracked Thermocouple Sheathing

316 SS

- Side View $75 x$

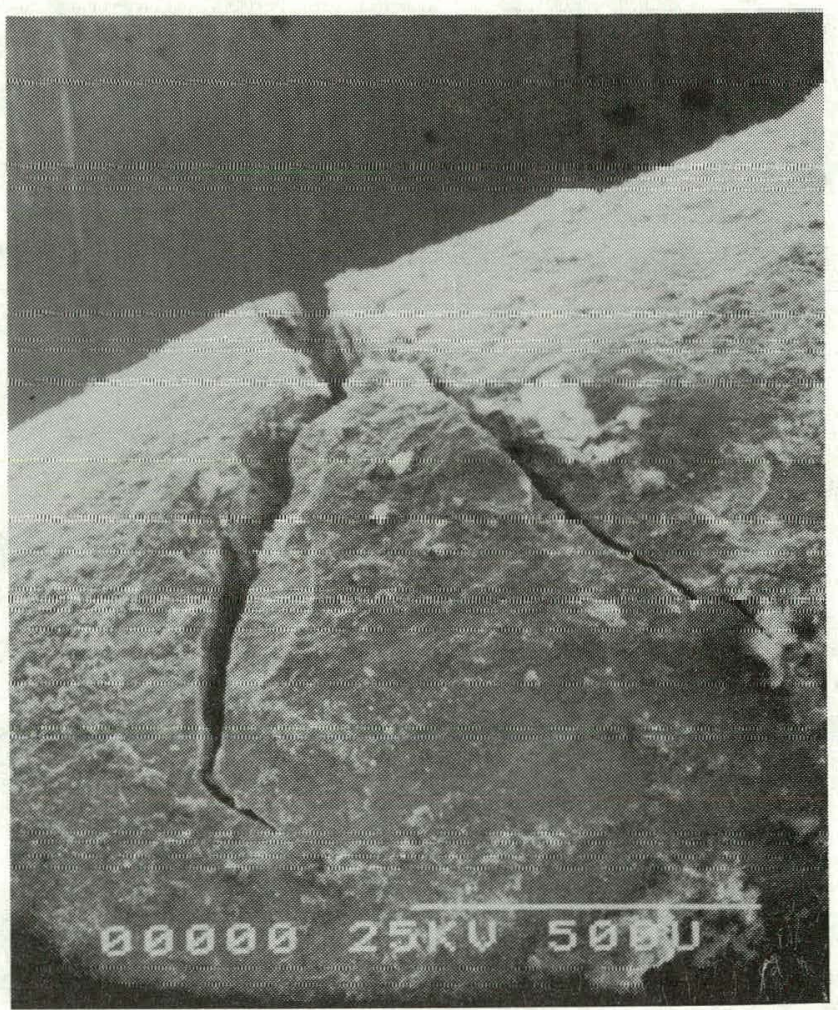




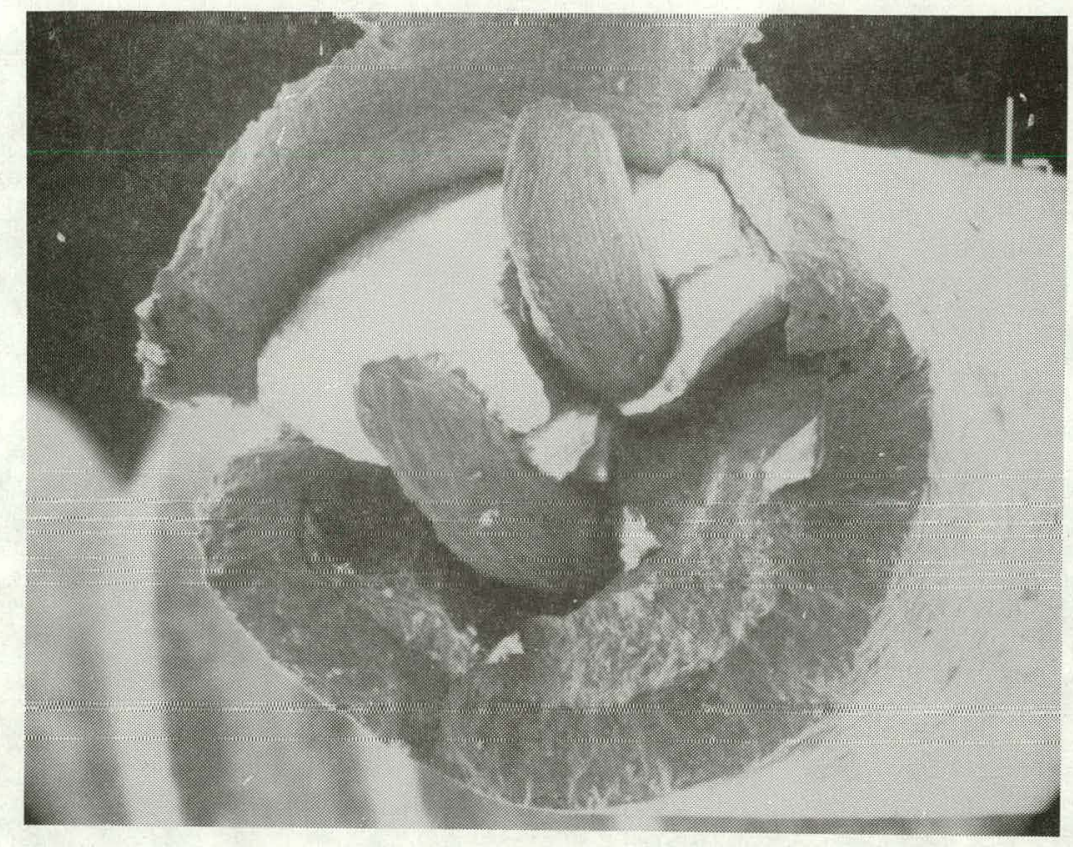

Figure 7. SEM of Cracked Thermocouple Sheathing - 316 SS - End View 45X

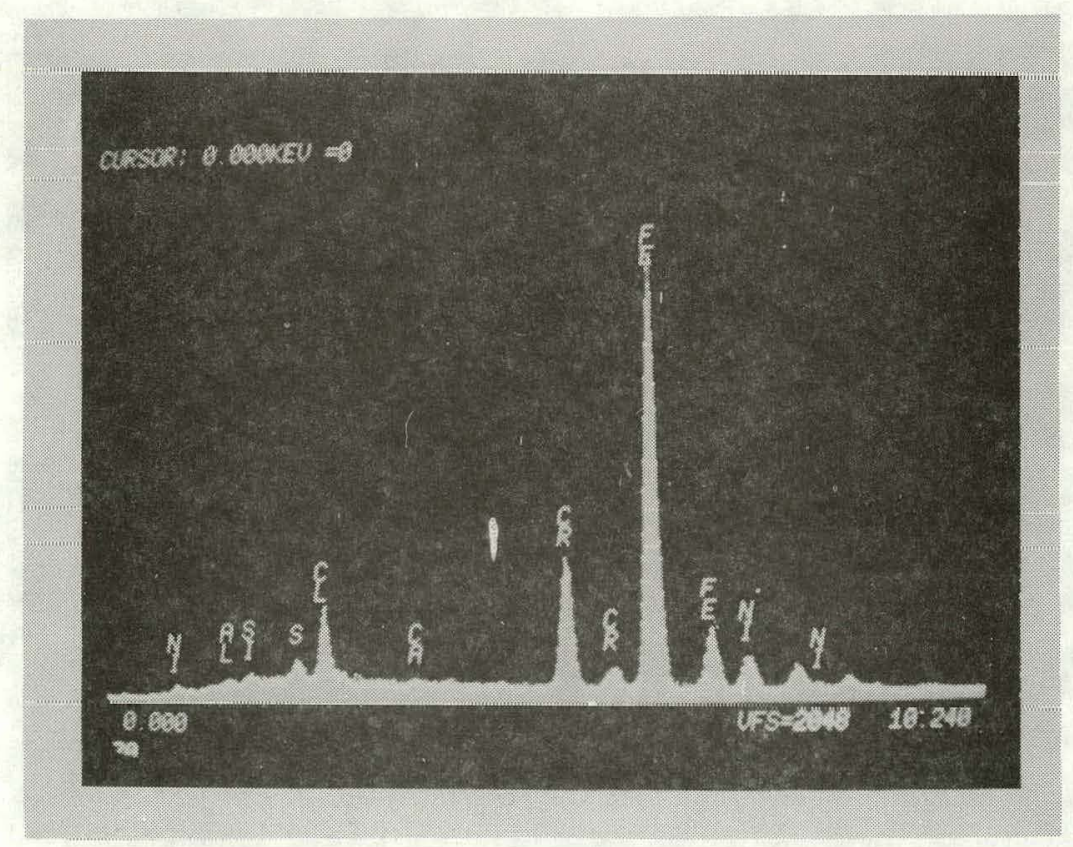

Figure 8. X-Ray Fluorescent Analysis - 316 Stainless Steel (Chloride) 


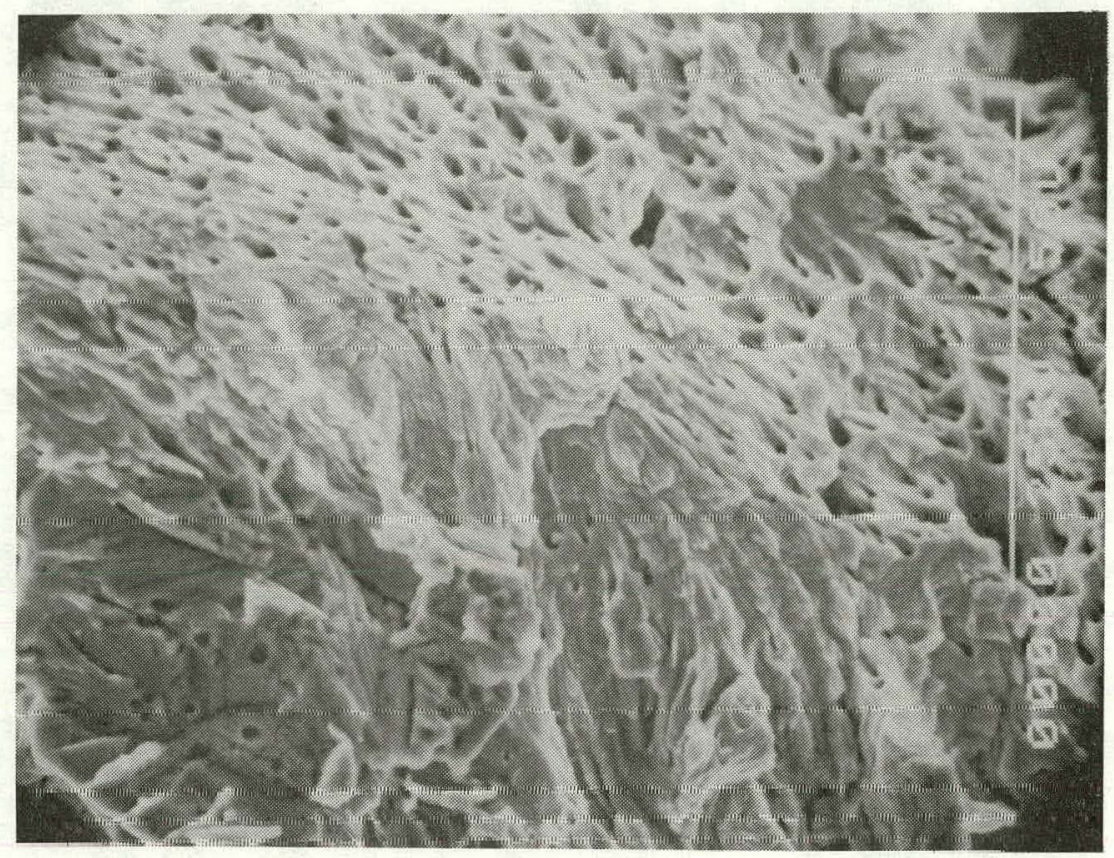

Figure 9. SEM of Thermocouple Fracture Surface - 316 SS

- Cracked to Overload 1000X

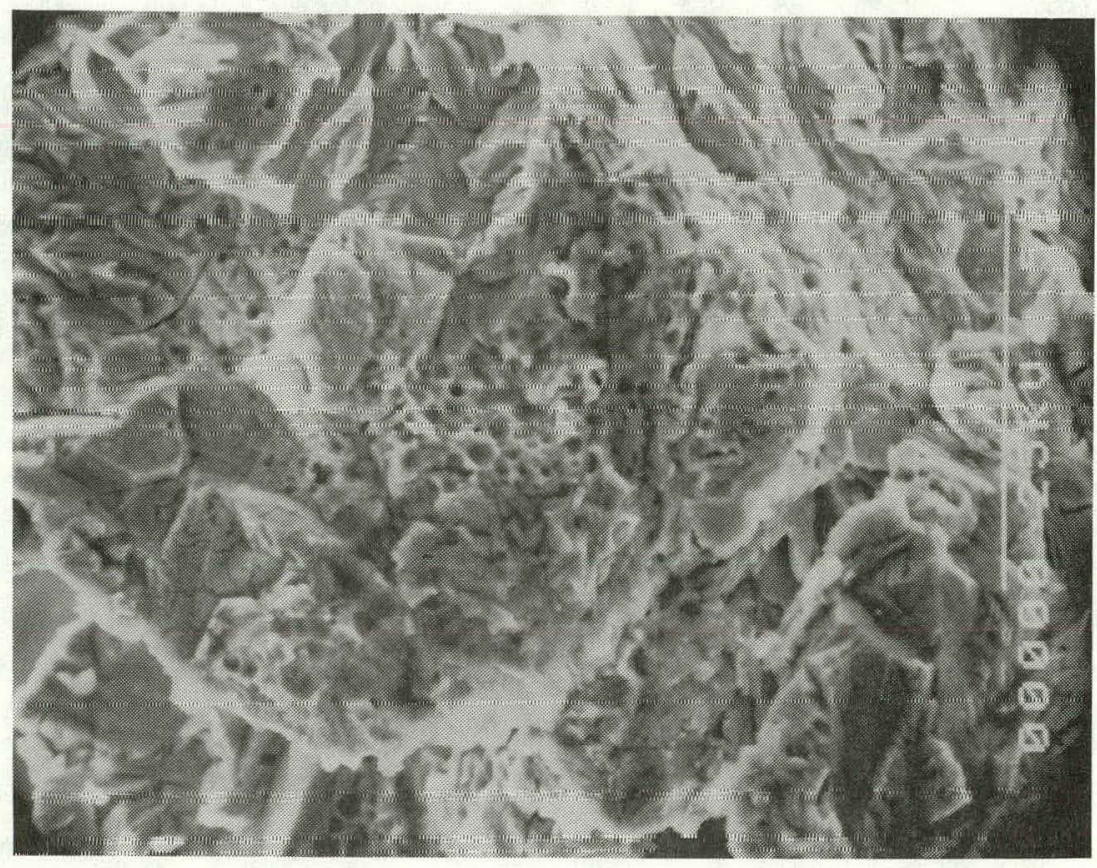

Figure 10. SEM of Thermocouple Fracture Surface - 316 SS

- Corroded to Cracked 1000X 


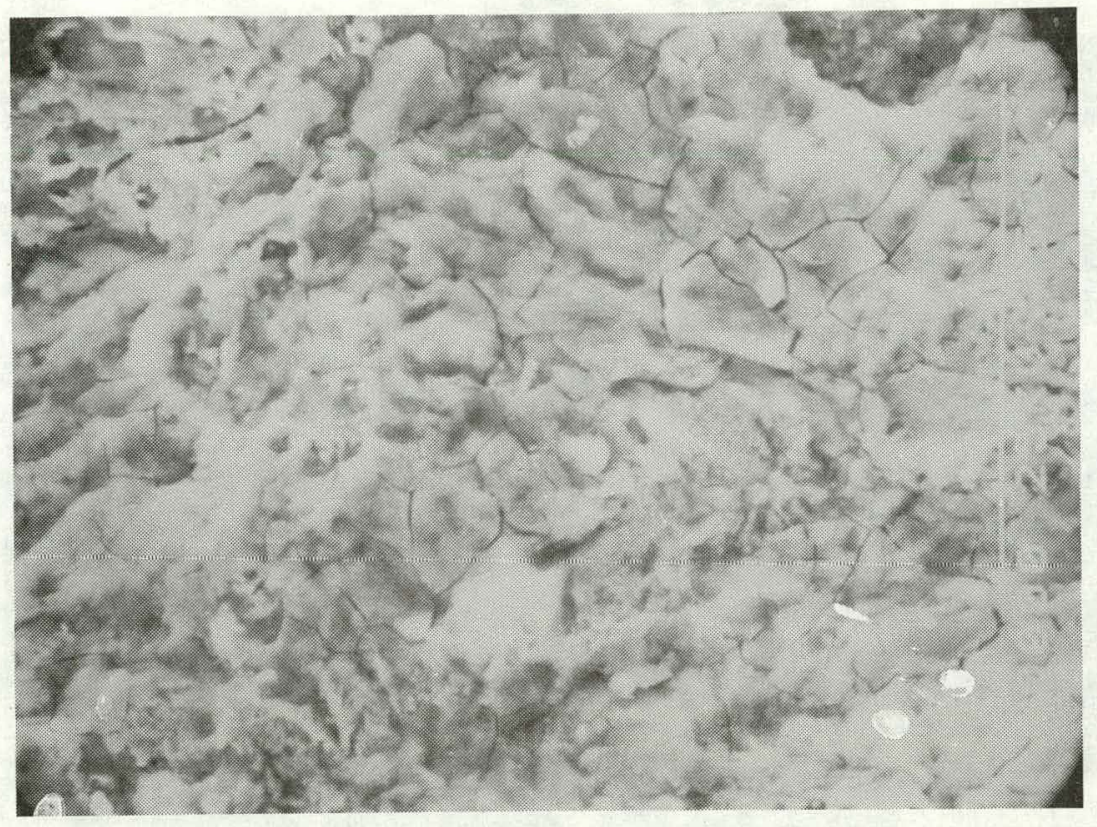

Figure 11. SEM of Thermocouple Fracture Surface - 316 SS - Corroded 1000X

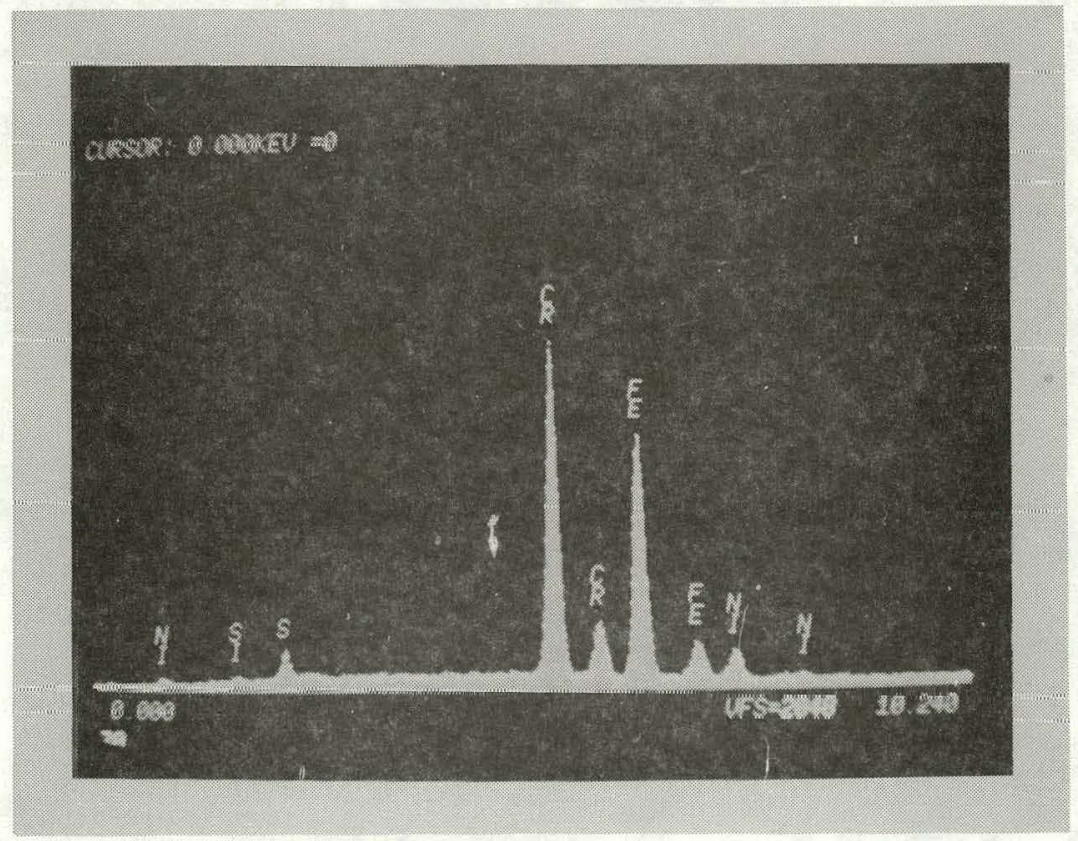

Figure 12. X-Ray Fluorescent Analysis of Corrosion Product on Thermocouple Fracture Surface - Chrome - Rich Oxide 


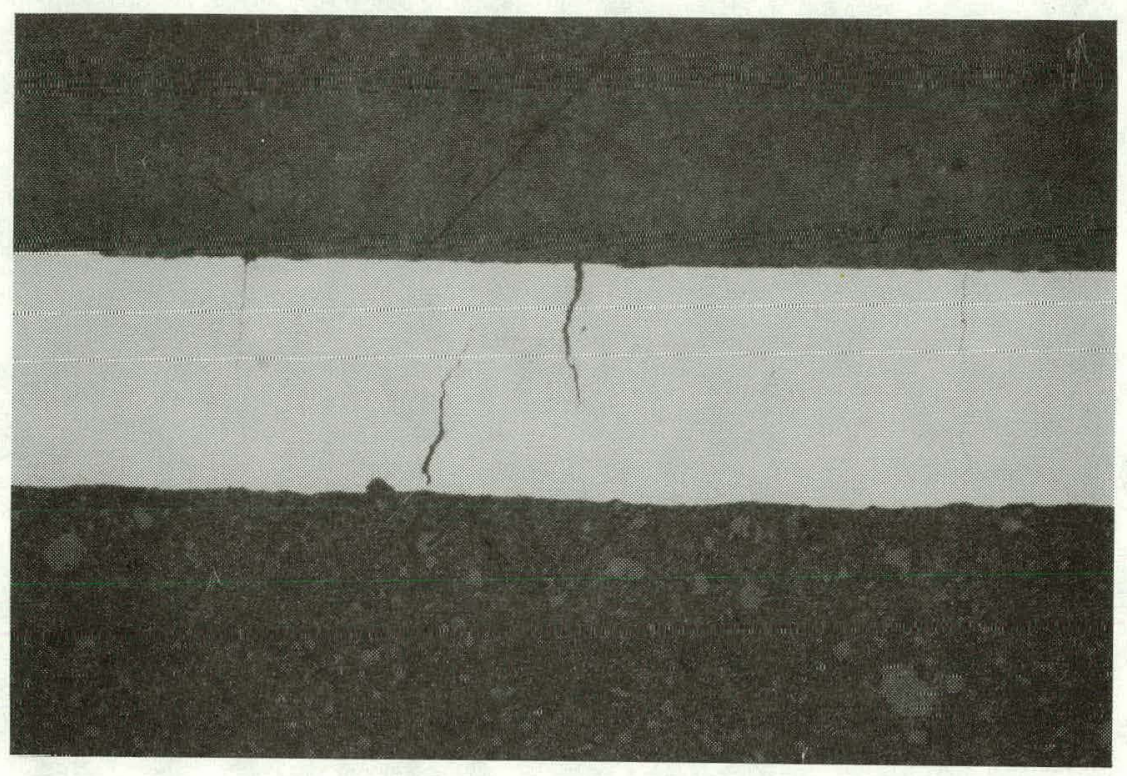

Figure 13. Metallographic Cross-Section of Thermocouple Sheathing

- 316 SS - Unetched 100x

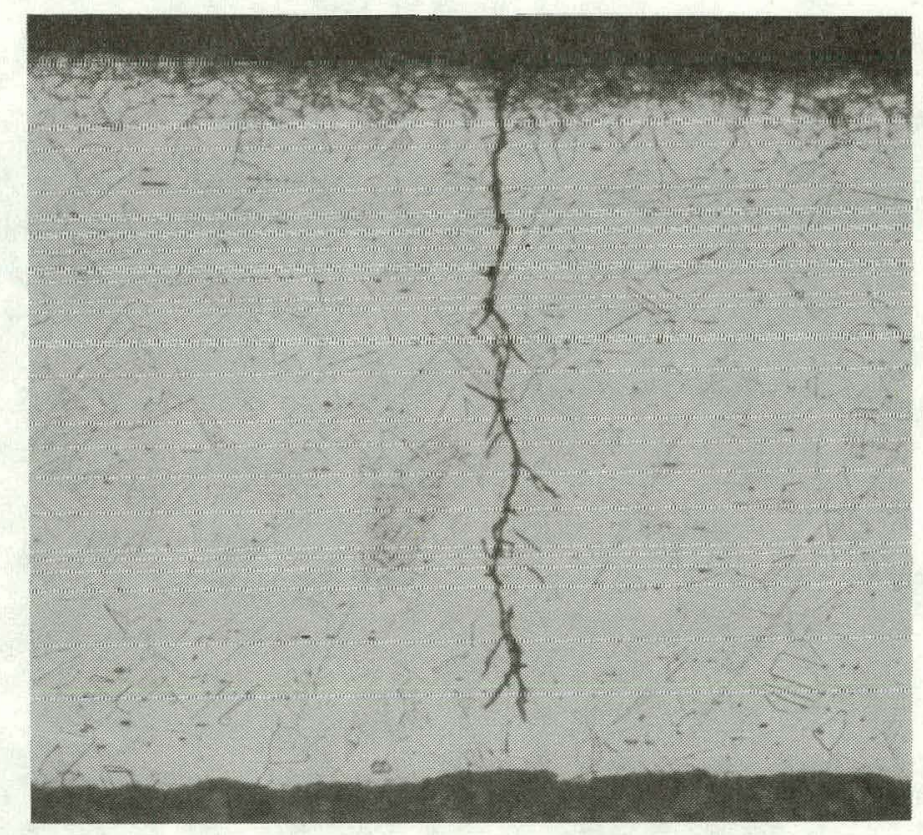

Figure 14. Metallographic Cross-Section of Thermocouple Sheathing - 316 SS - Etched 320X 


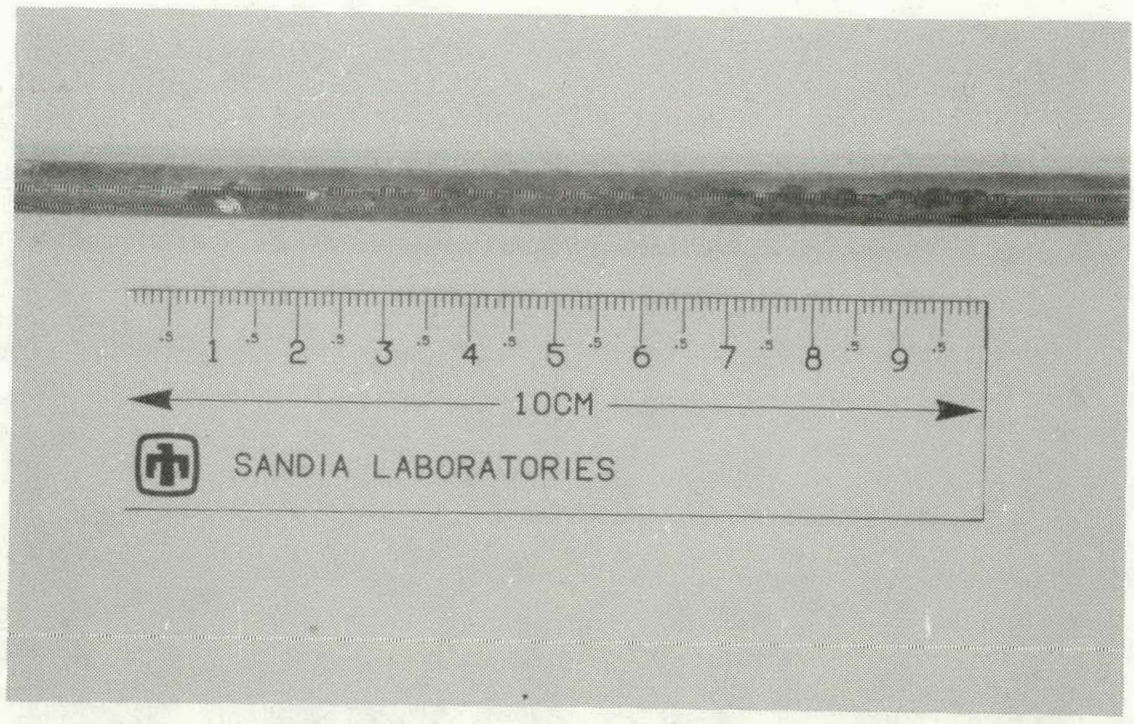

Figure 15. Macrograph of 316 Stainless Steel Tubing - Linear Pitting

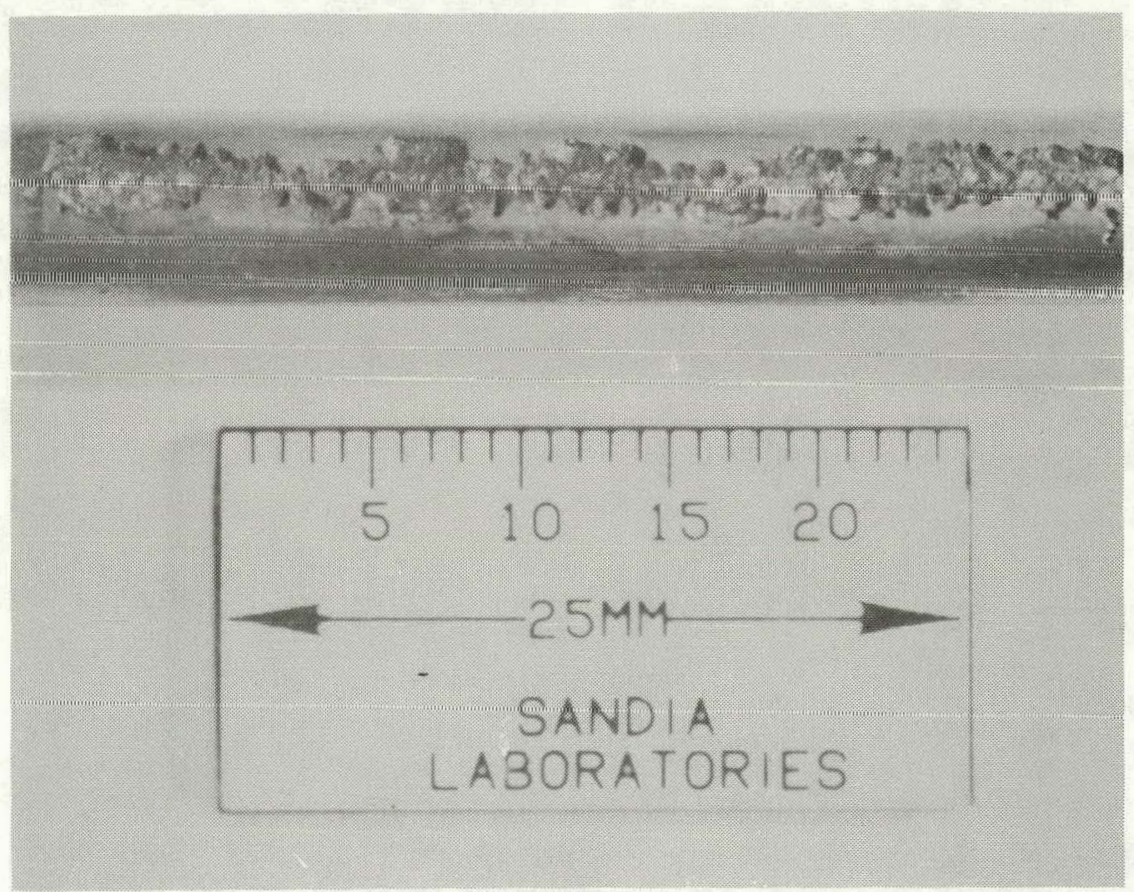

Figure 16. Macrograph of 316 Stainless Steel Tubing 


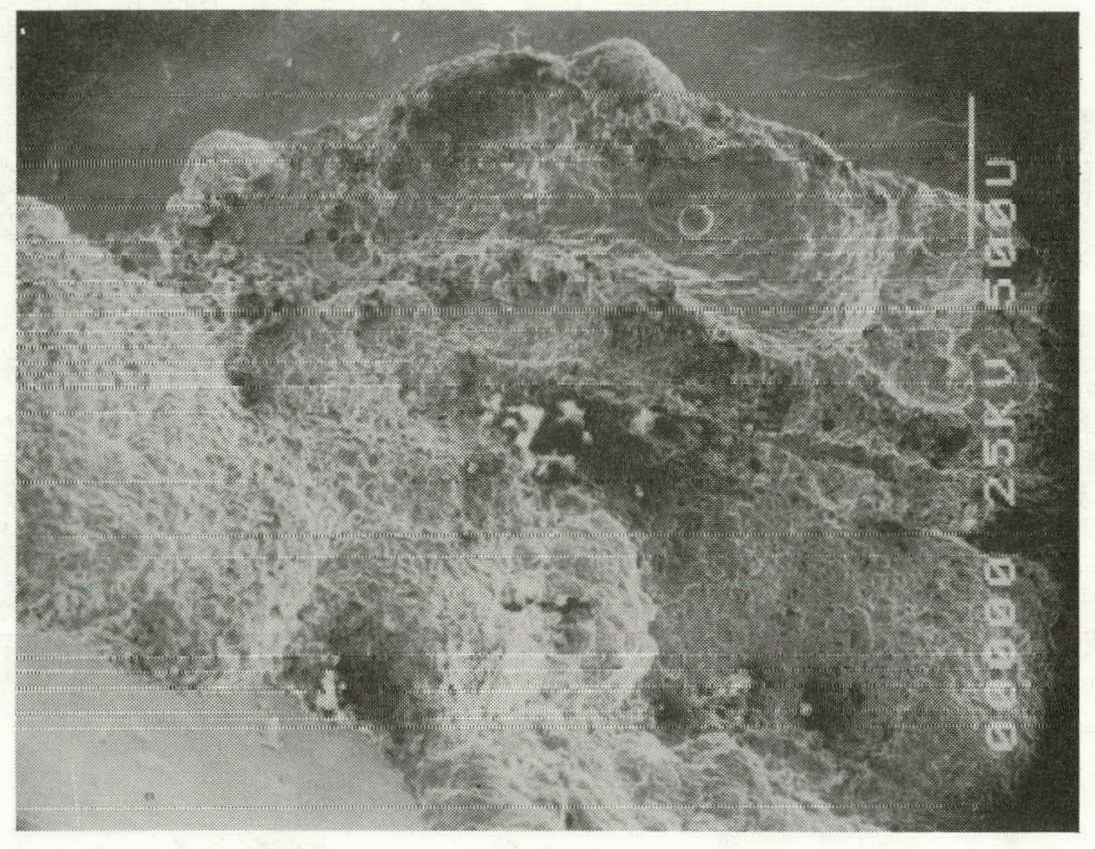

Figure 17. SEM of Pit in 316 SS Tubing - 50X

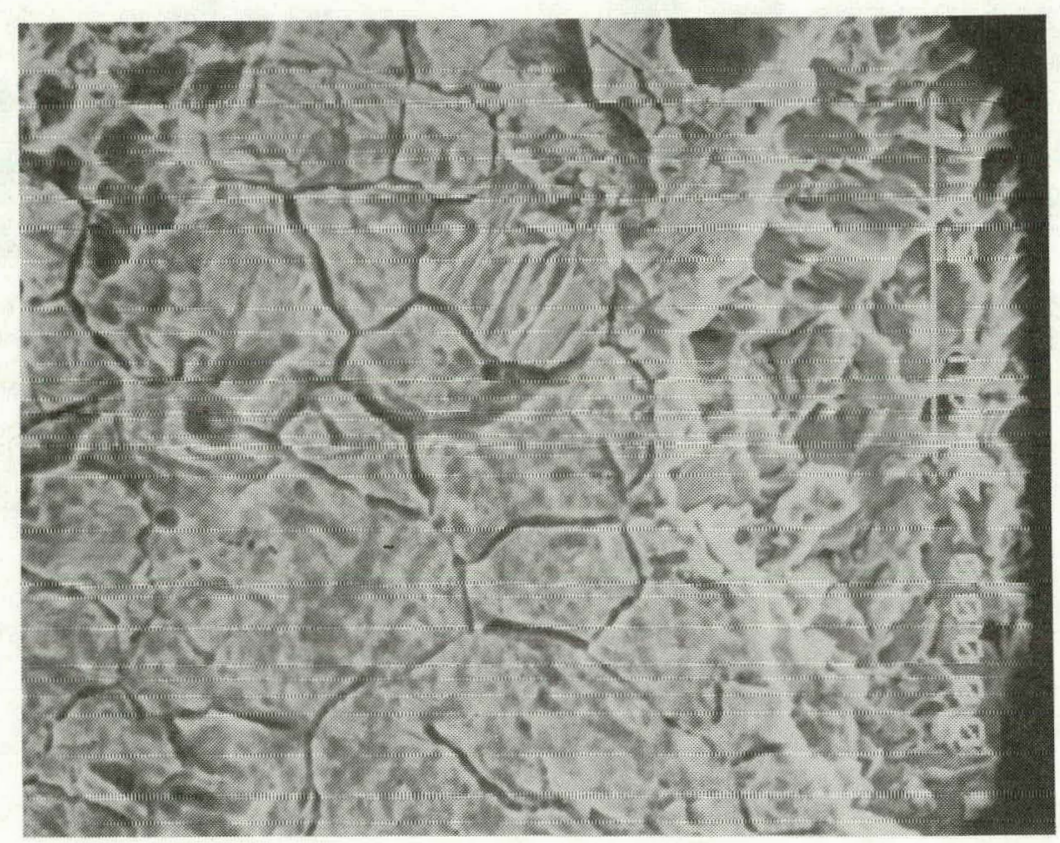

Figure 18. SEM of Intergranular Attack and Pitting in 316 SS Tubing - 750X 


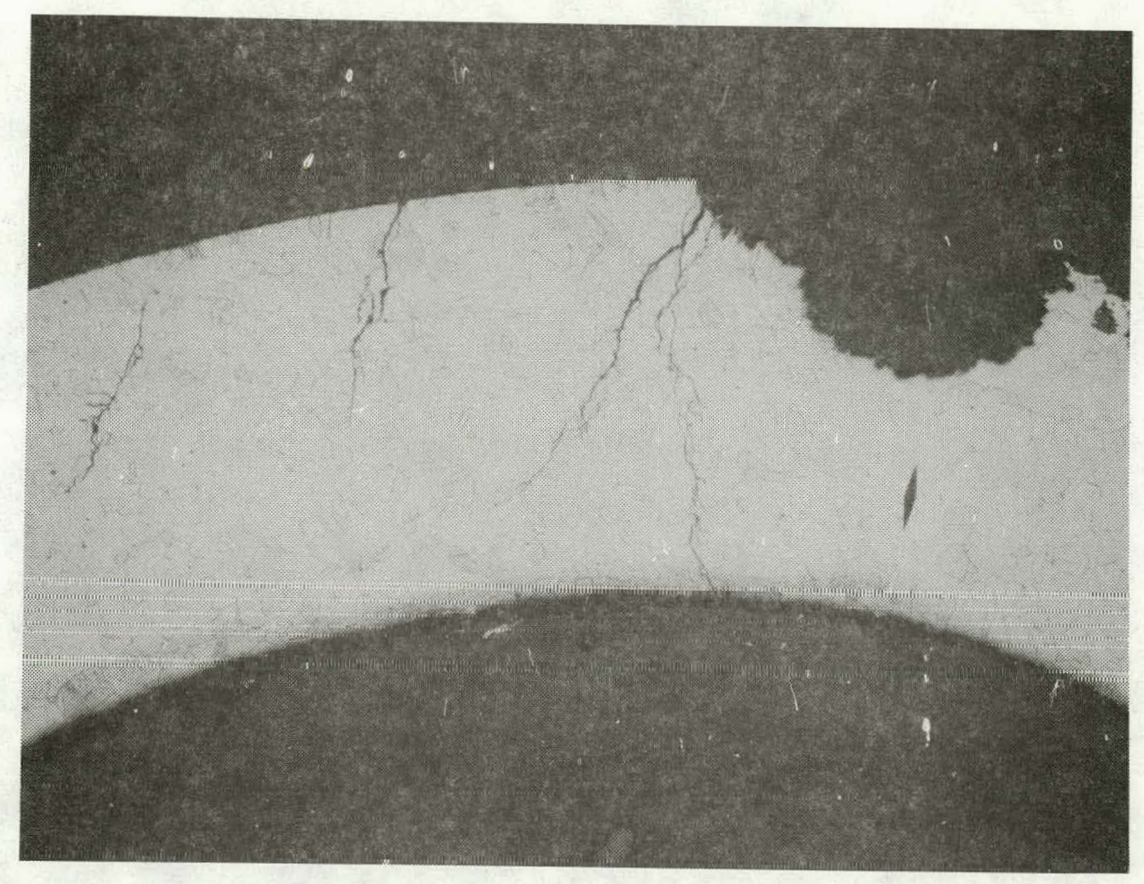

Figure 19. Metallographic Cross-Section of Pit in 316 SS Tubing - Etched 63X

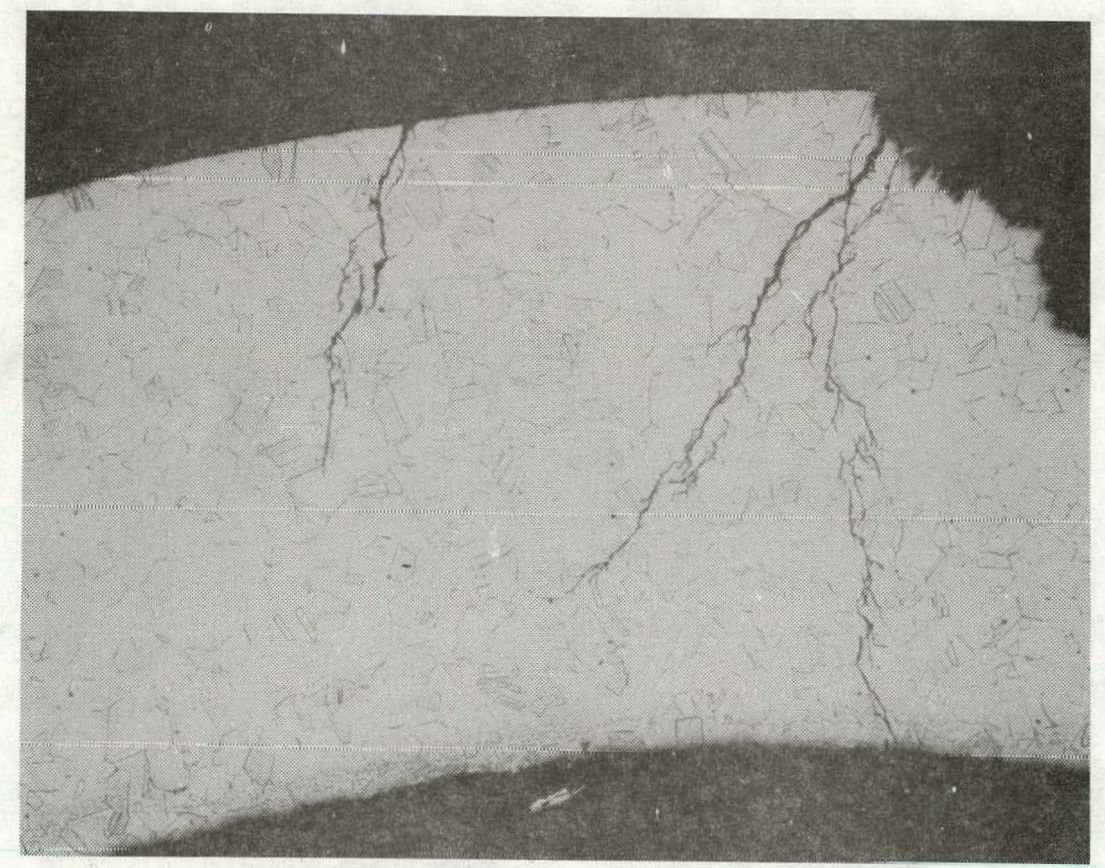

Figure 20. Metallographic Cross-Section of Pit in 316 SS Tubing - Etched 100X 


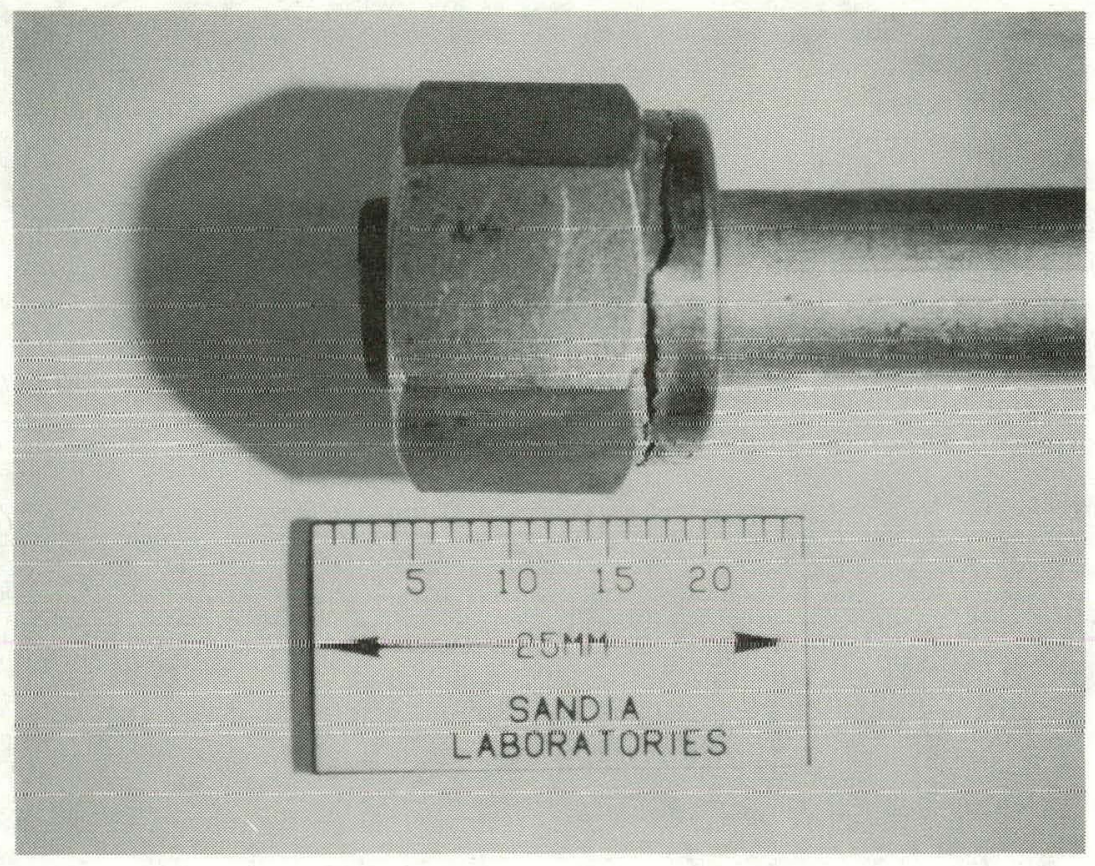

Figure 21. Macrograph of 316 SS Swagelok Nut - Caustic Line

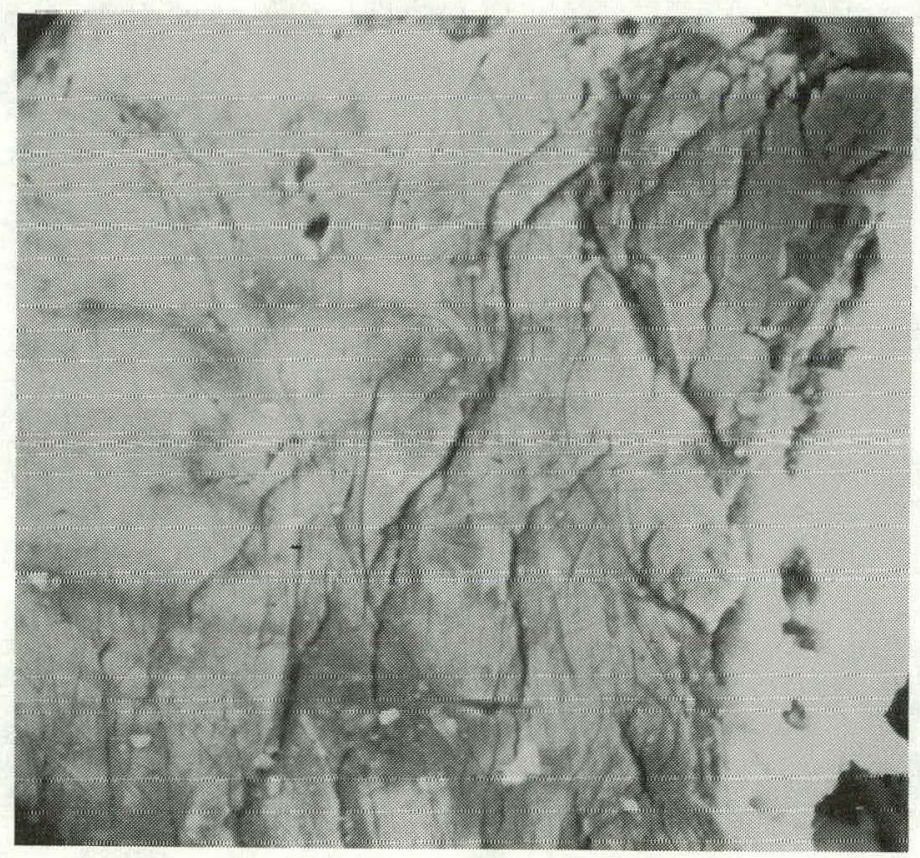

Figure 22. SEM of Secondary Cracking at Edge of Primary Crack 1000X

- 316 SS Swagelok Nut 


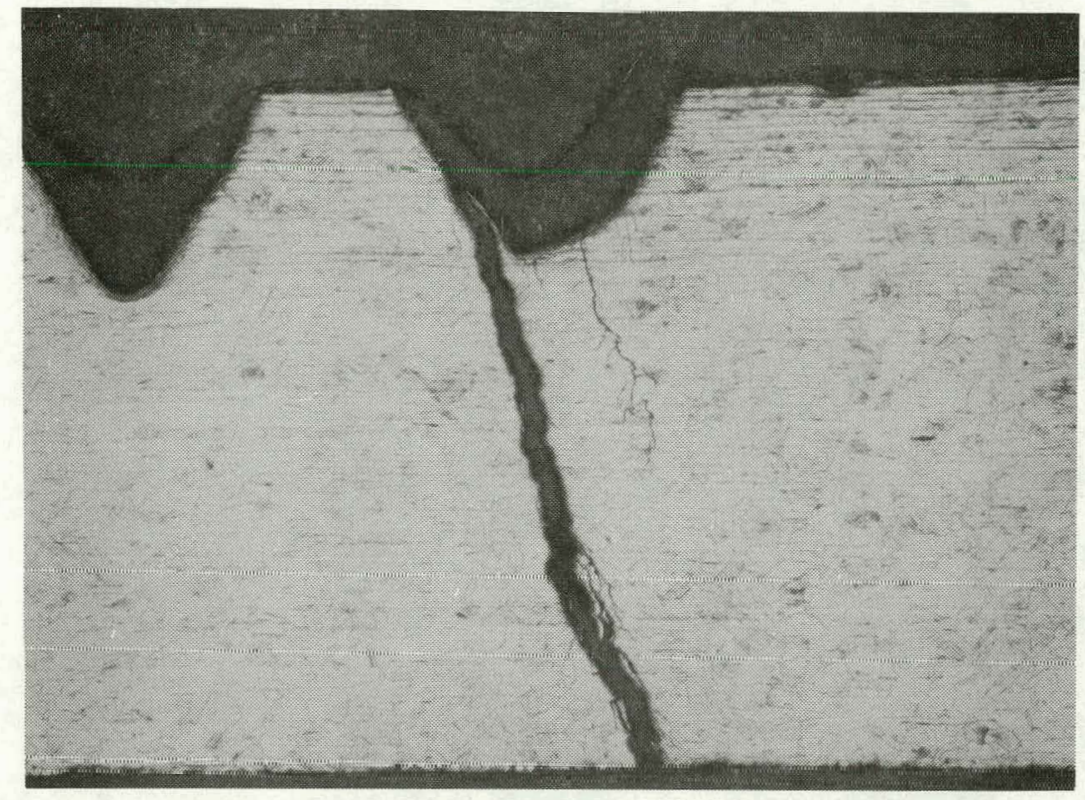

Figure 23. Metallographic Cross-Section of 316 SS Swagelok Nut at Primary Crack - Etched $30 x$

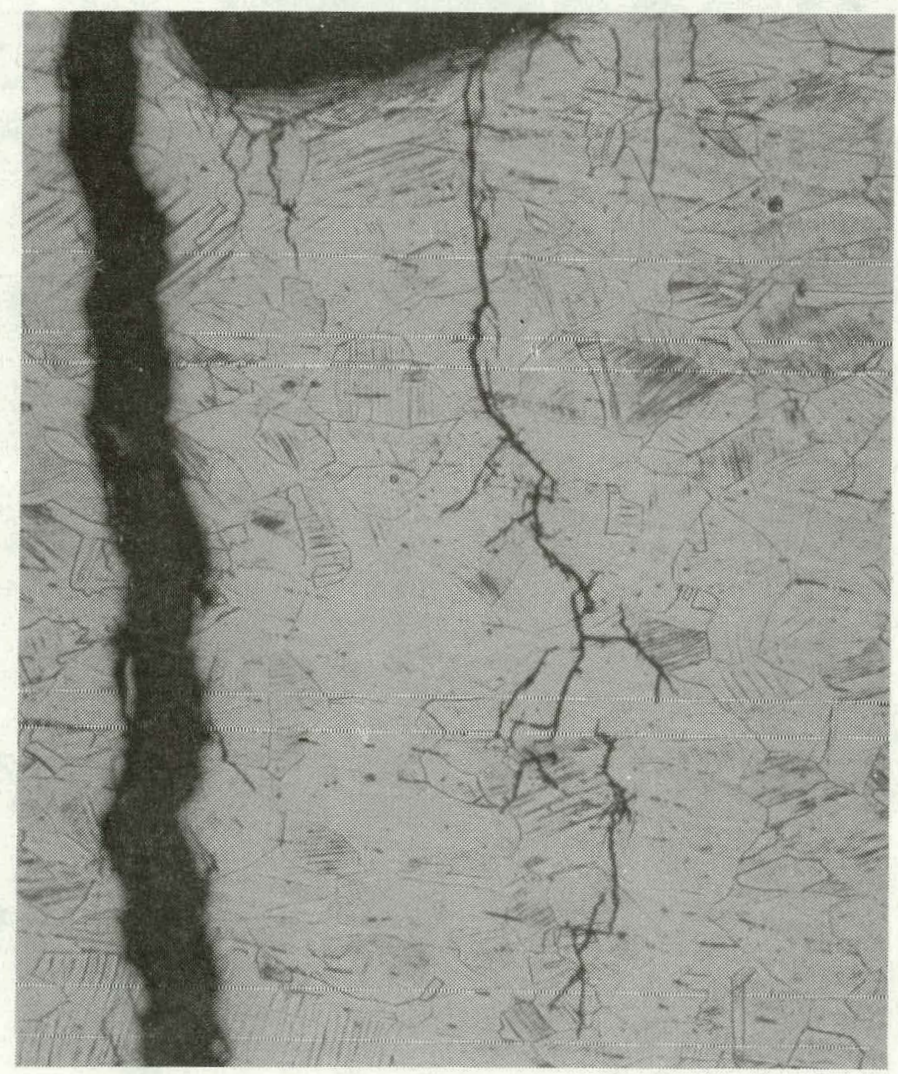

Figure 24. Metallography of Secondary Crack in 316 SS Swagelok Nut. 


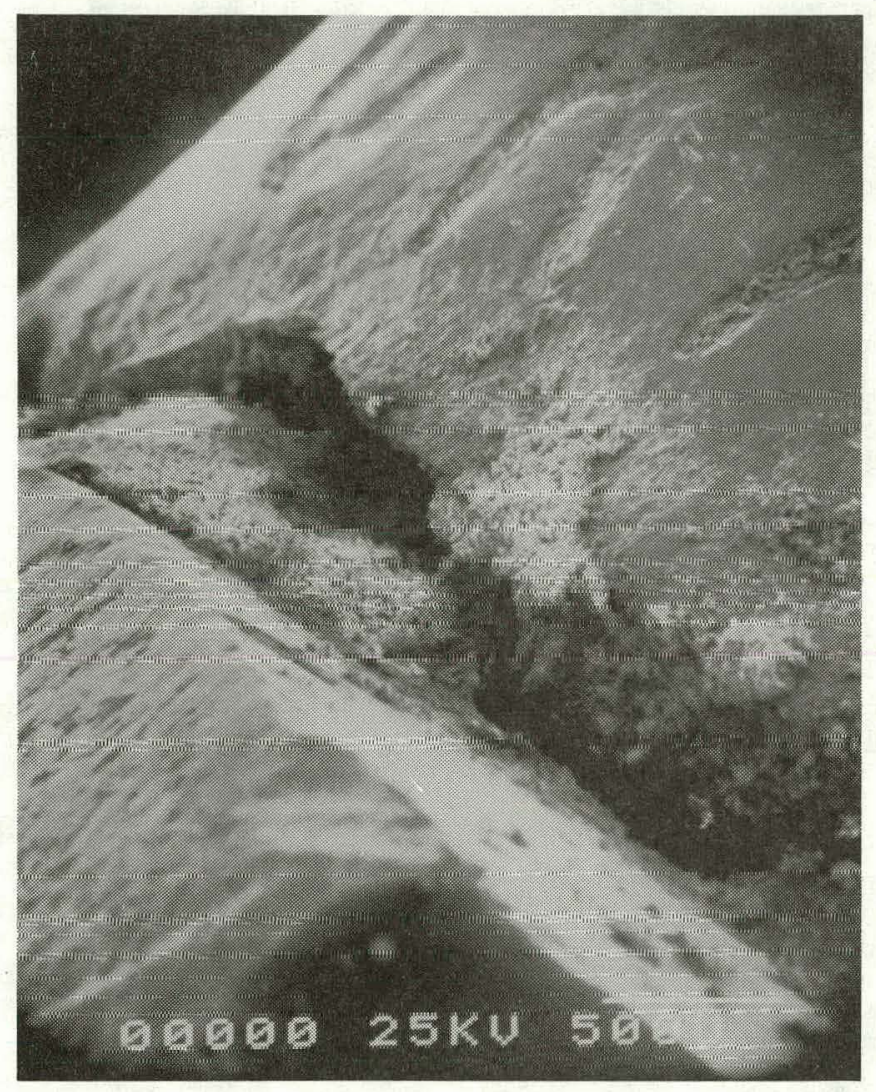

Figure 25. SEM of Primary Crack in 316 SS Swagelok Nut with Material Deposit 35X

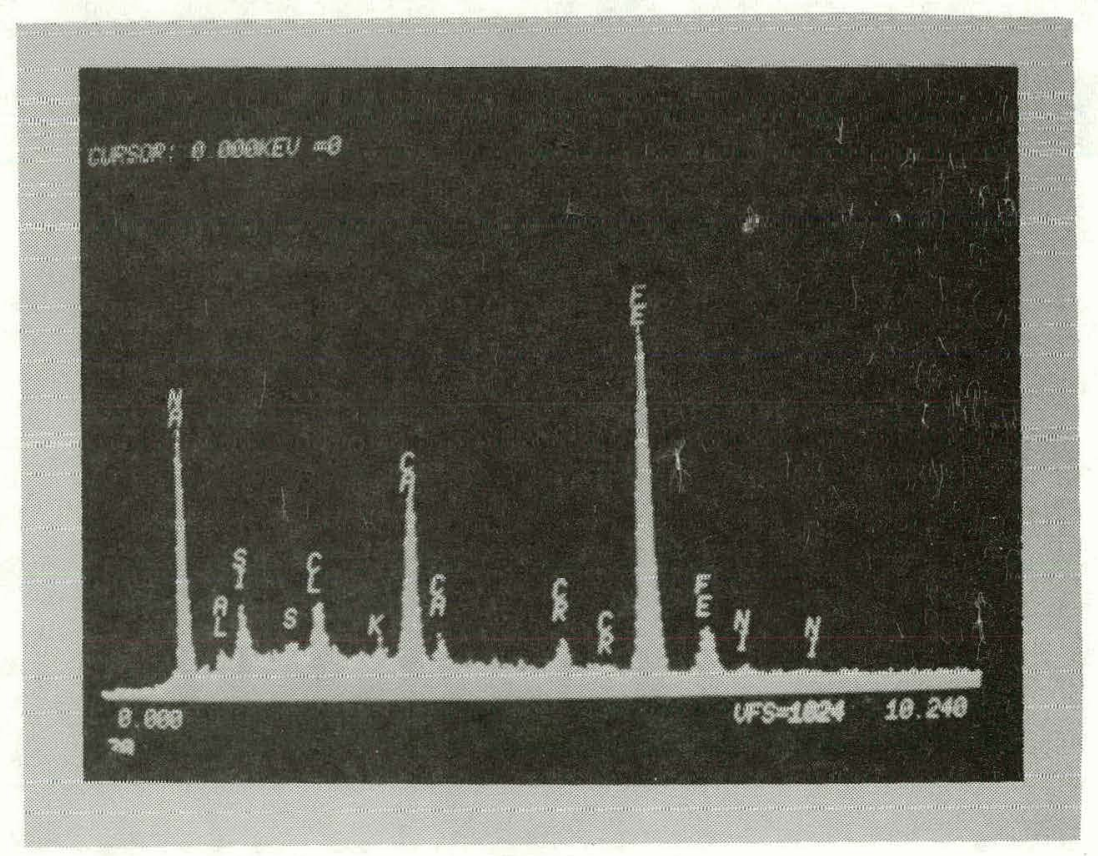

Figure 26. X-Ray Fluorescent Analysis of Material Deposit on 316 SS Swagelok Nut 


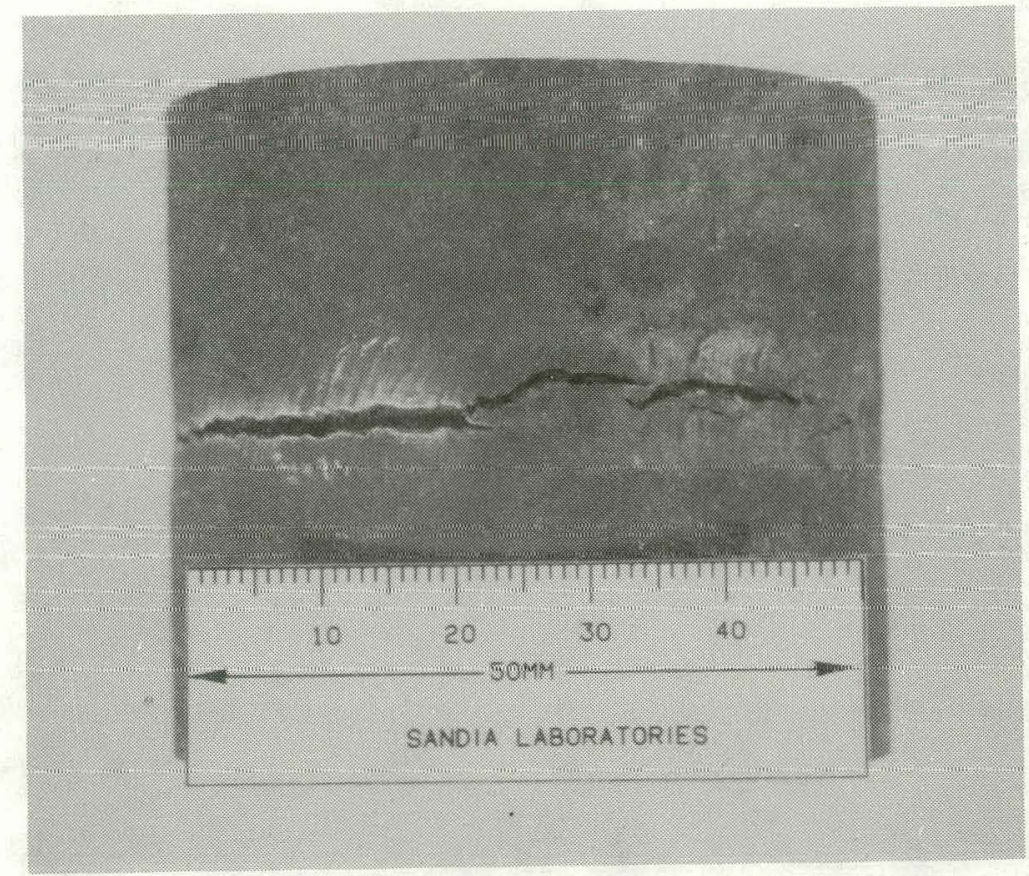

Figure. 27. Macrograph of 310 SS to 310 SS Weld in Air/Diesel DSG Outlet Pipe

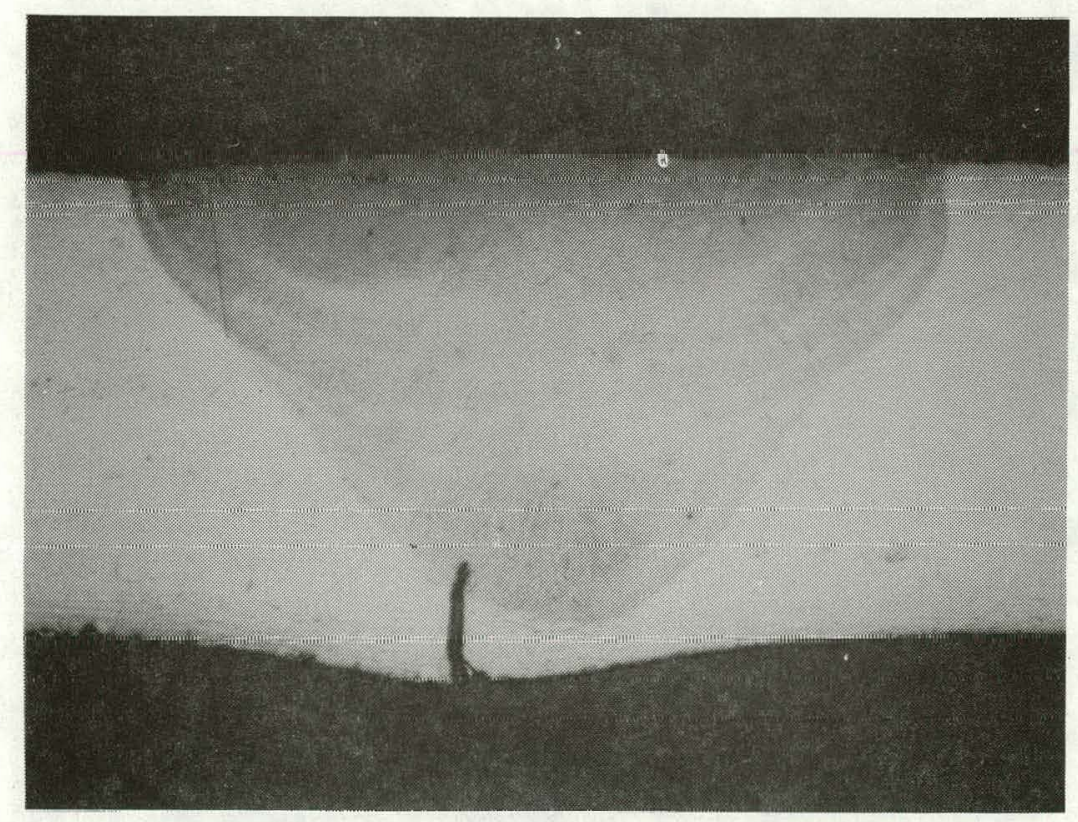

Figure 28. Metallographic Cross-Section of Weld Zone in 310 ss Outlet Pipe

- Lack of Weld Penetration 9X 


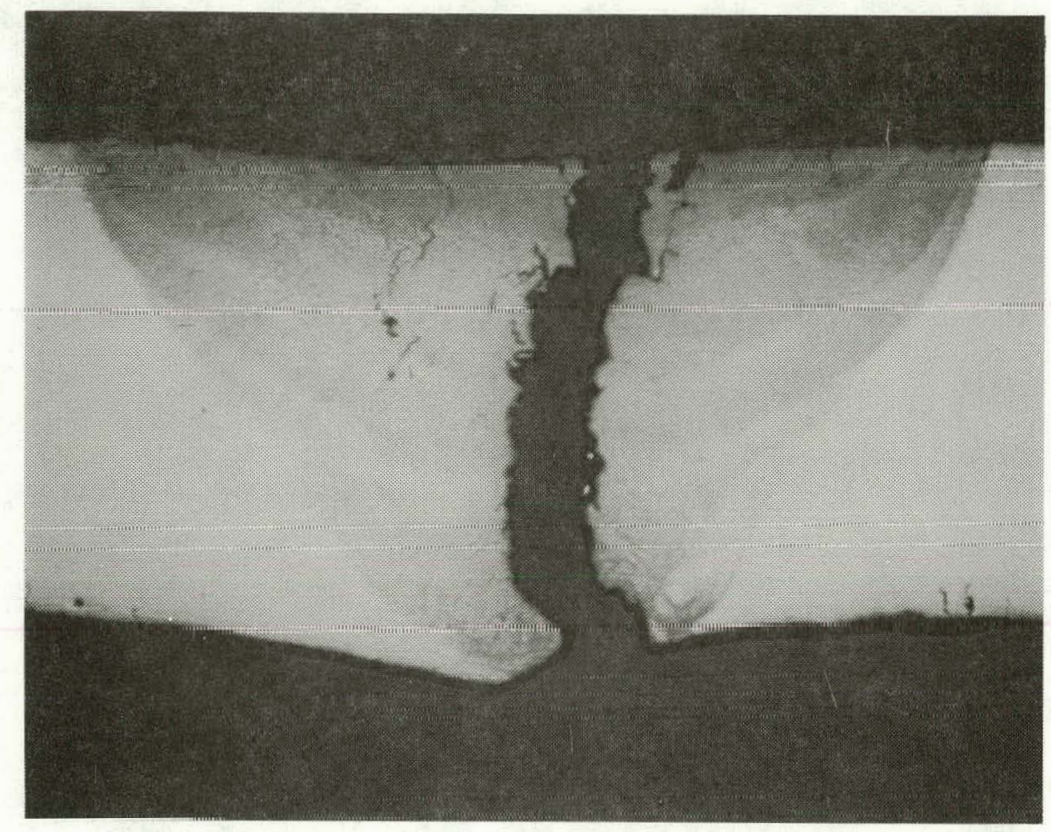

Figure 29. Metallographic Cross-Section of Weld Zone in 310 ss Outlet Pipe - Cracked 9X

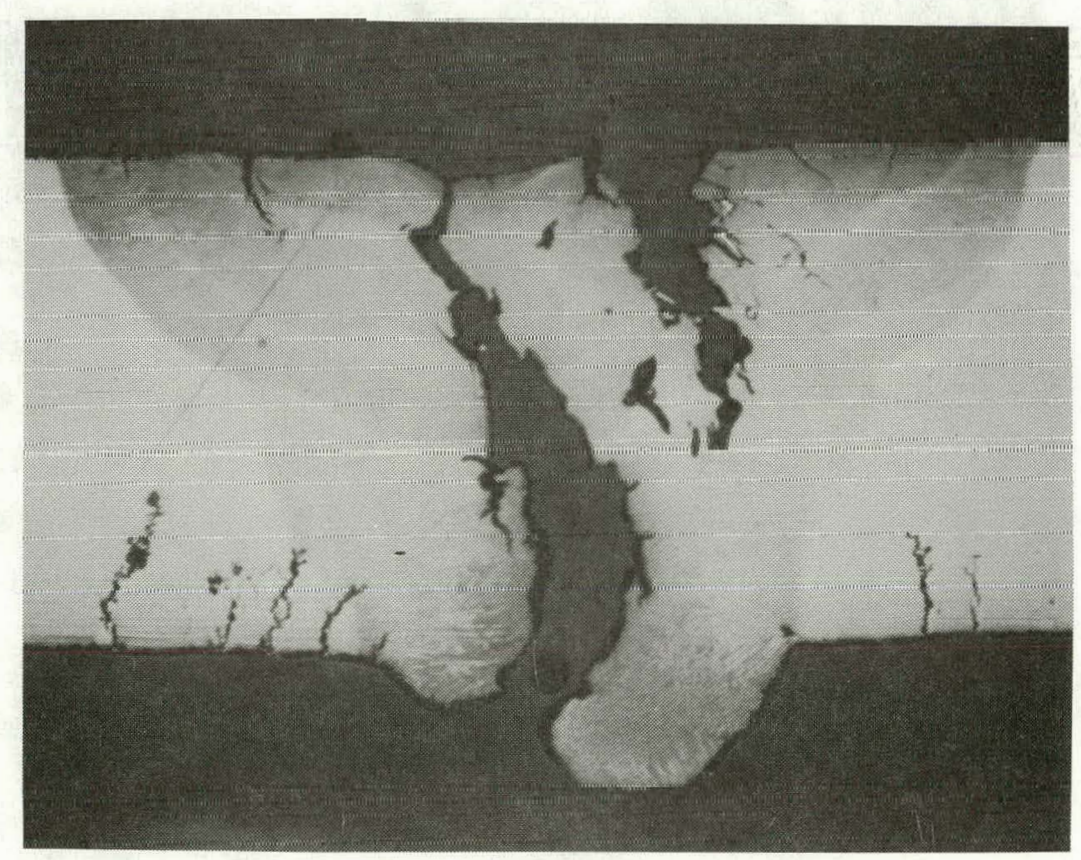

Figure 30. Metallographic Cross-Section of Weld Zone in 310 ss Outlet Pipe 


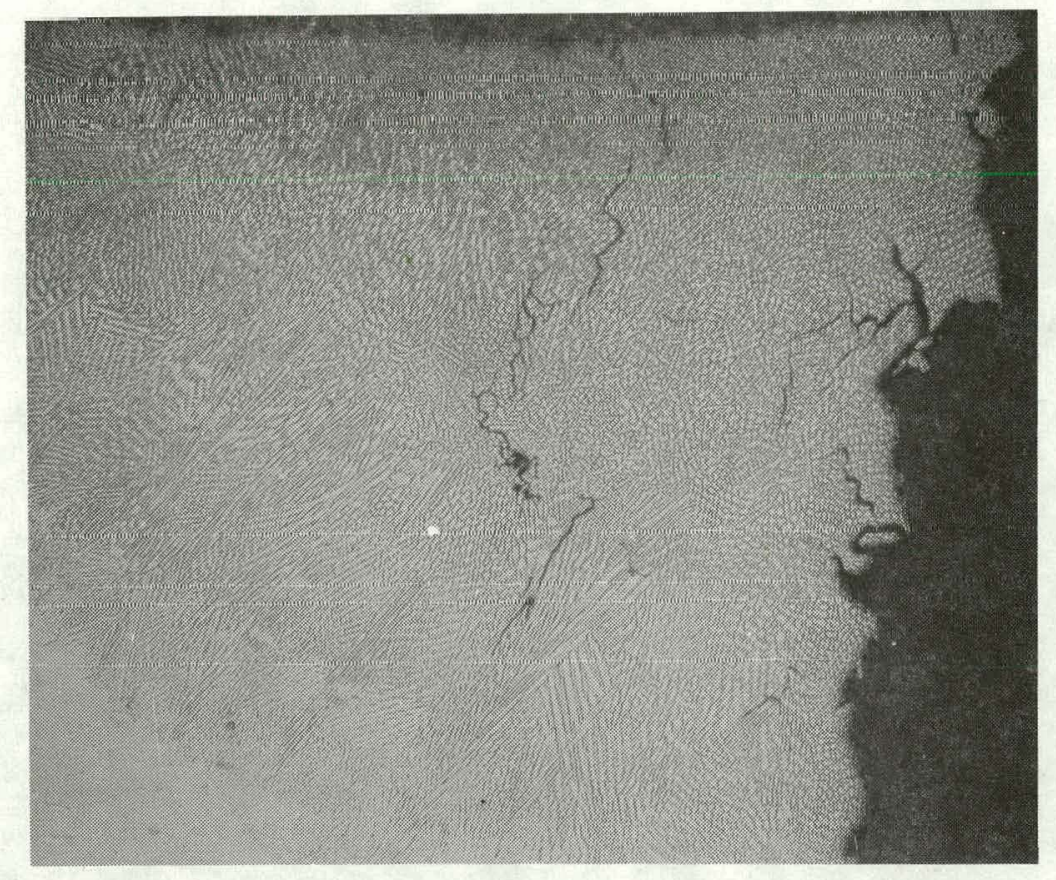

Figure 31. Metallography of Weld Metal in 310 SS Outlet Pipe 25X

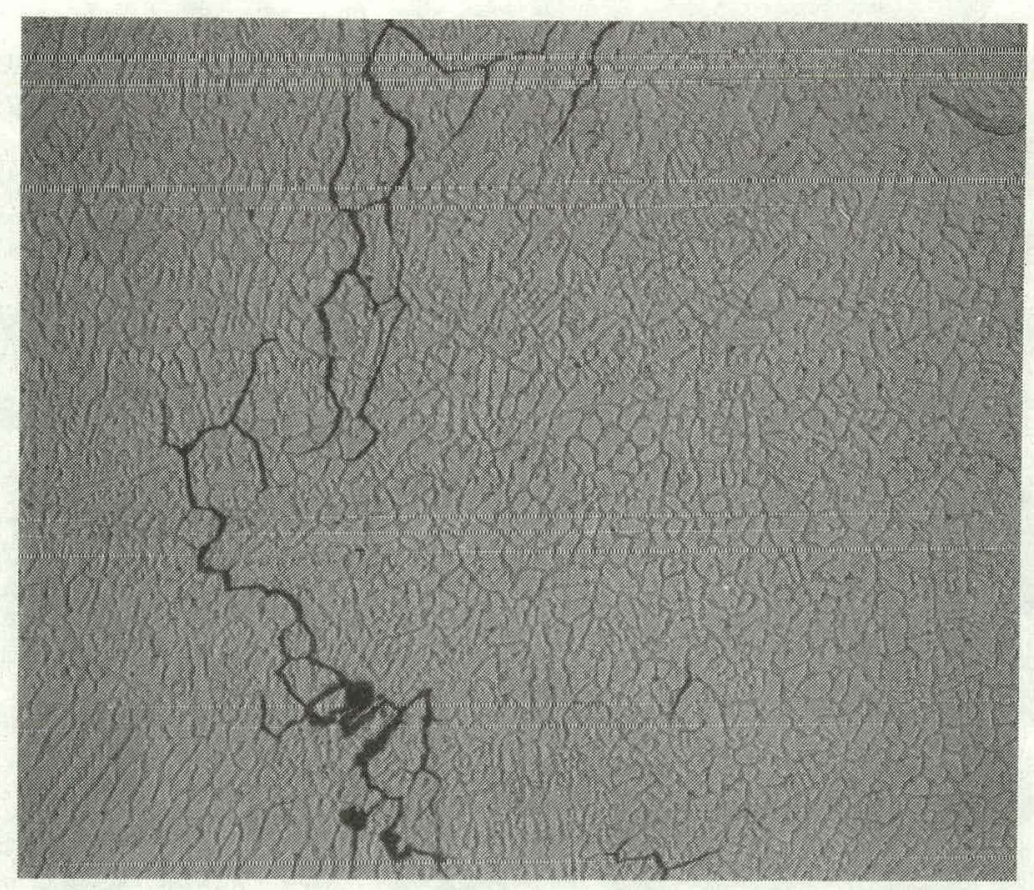

Figure 32. Intergranular Crack Path in 310 SS Weld Metal 100X 


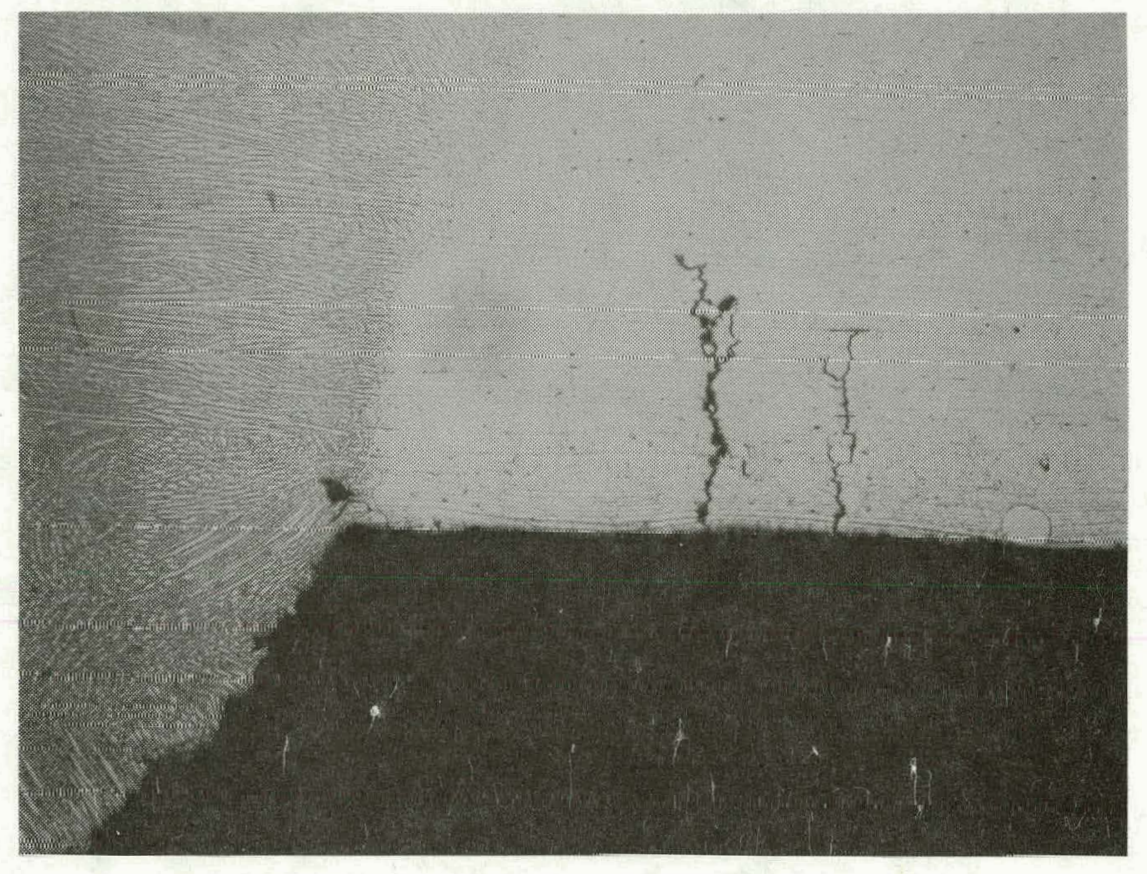

Figure 33. Metallography of Parent Metal in 310 SS Outlet Pipe 25X

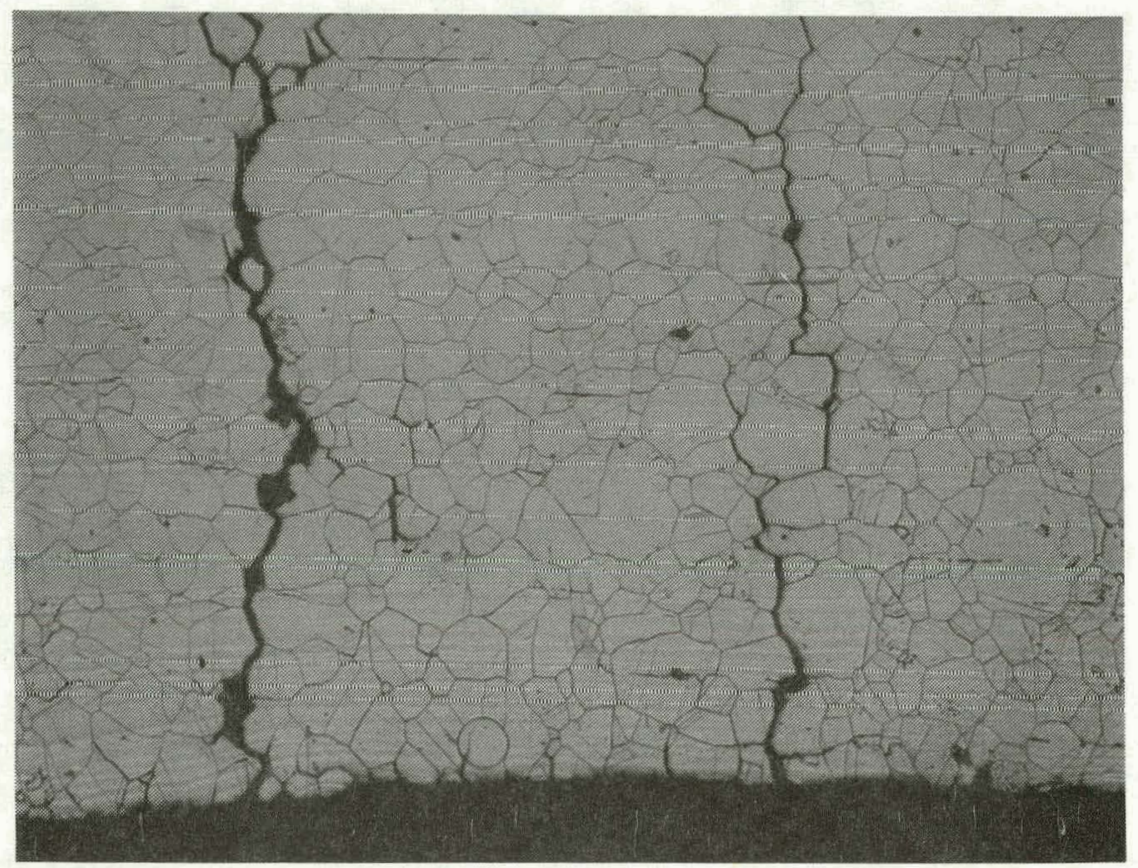

Figure 34. Intergranular Crack Path in 310 SS Parent Meta1 100X 


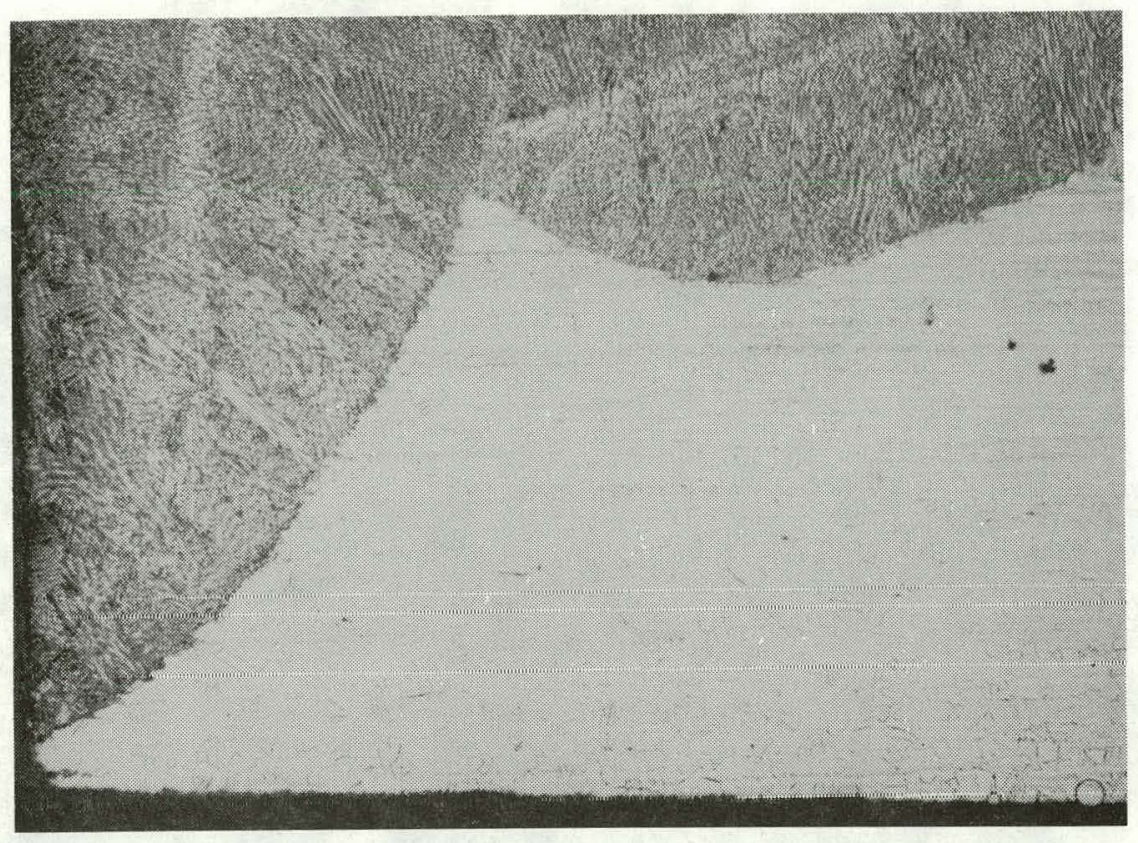

Figure 35. Weld Joint at Bottom End of 310 SS Air/Diesel Generator 31X

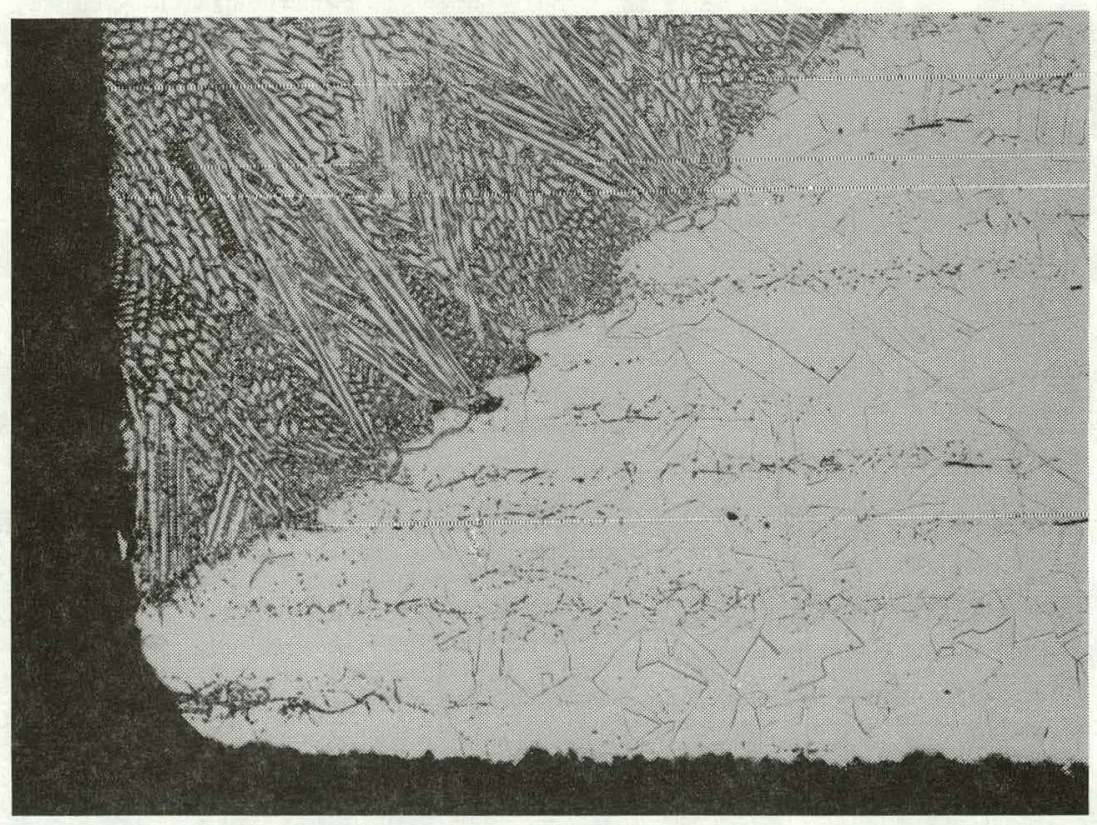

Figure 36. Weld Joint at Bottom End of 310 SS Air/Diesel Generator 100X 


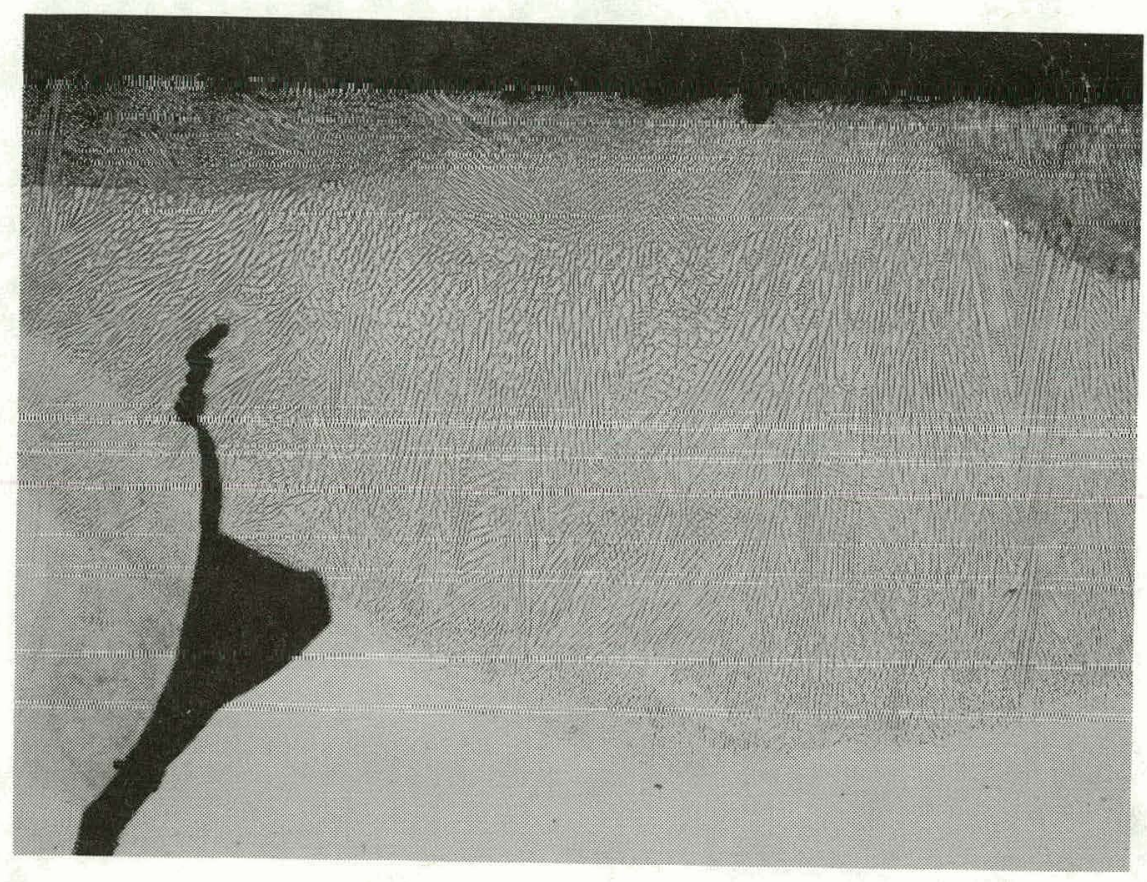

Figure 37. Weld Joint at Bottom End of 310 SS Air/Diese1 Generator 


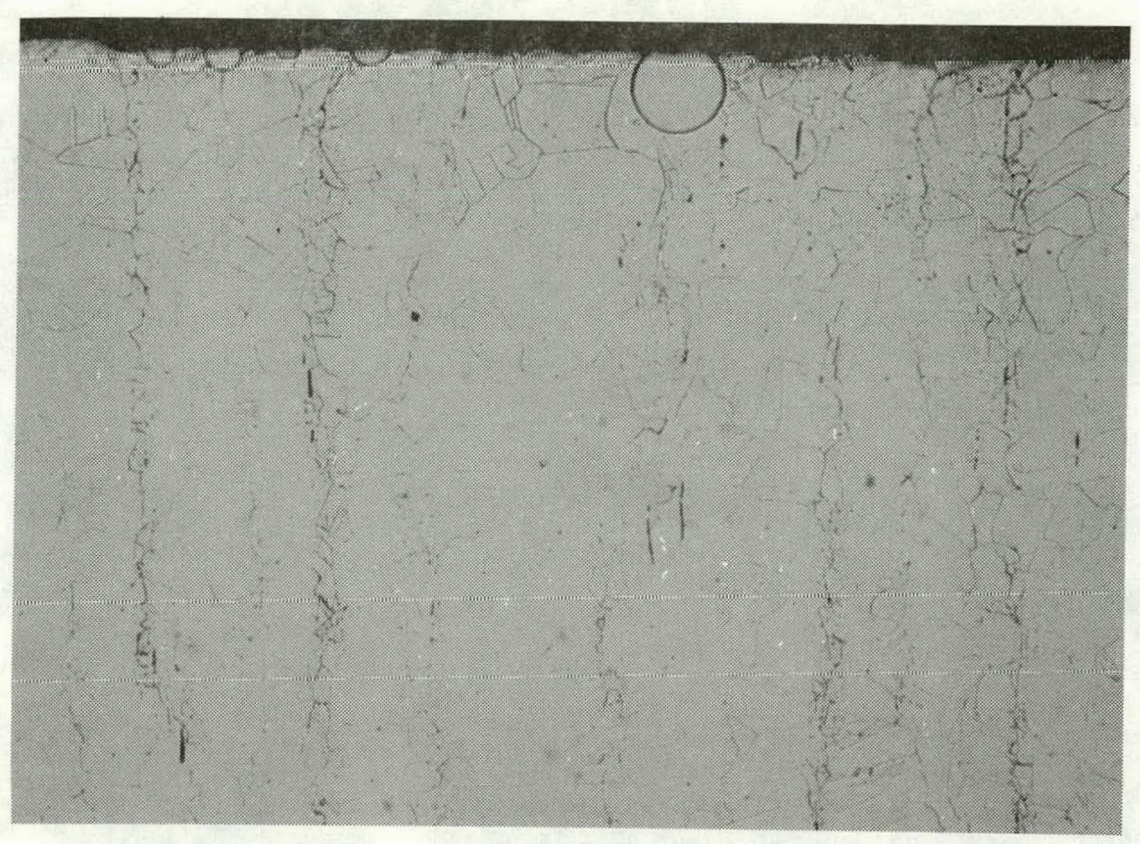

Figure 38. Surface of 310 SS Generator Showing Microsegregation 100X

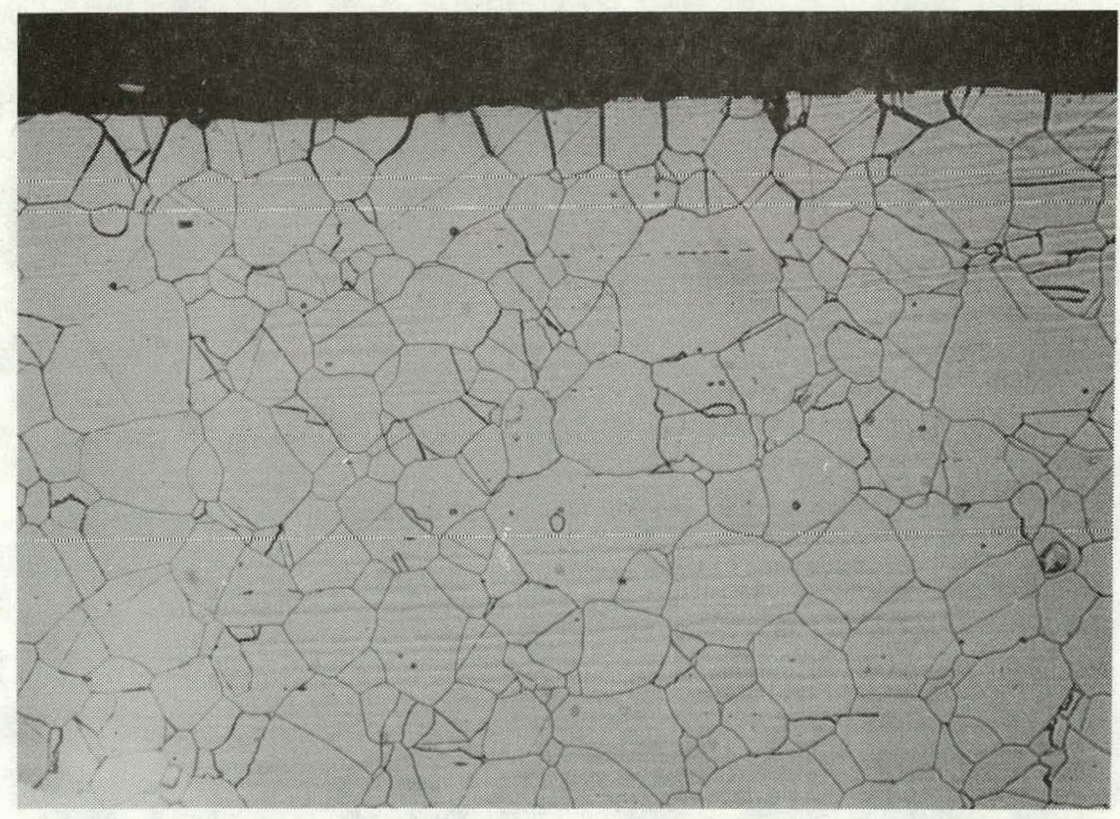

Figure 39. Surface of 310 SS Generator Showing Intergranular Attack $100 \mathrm{x}$ 


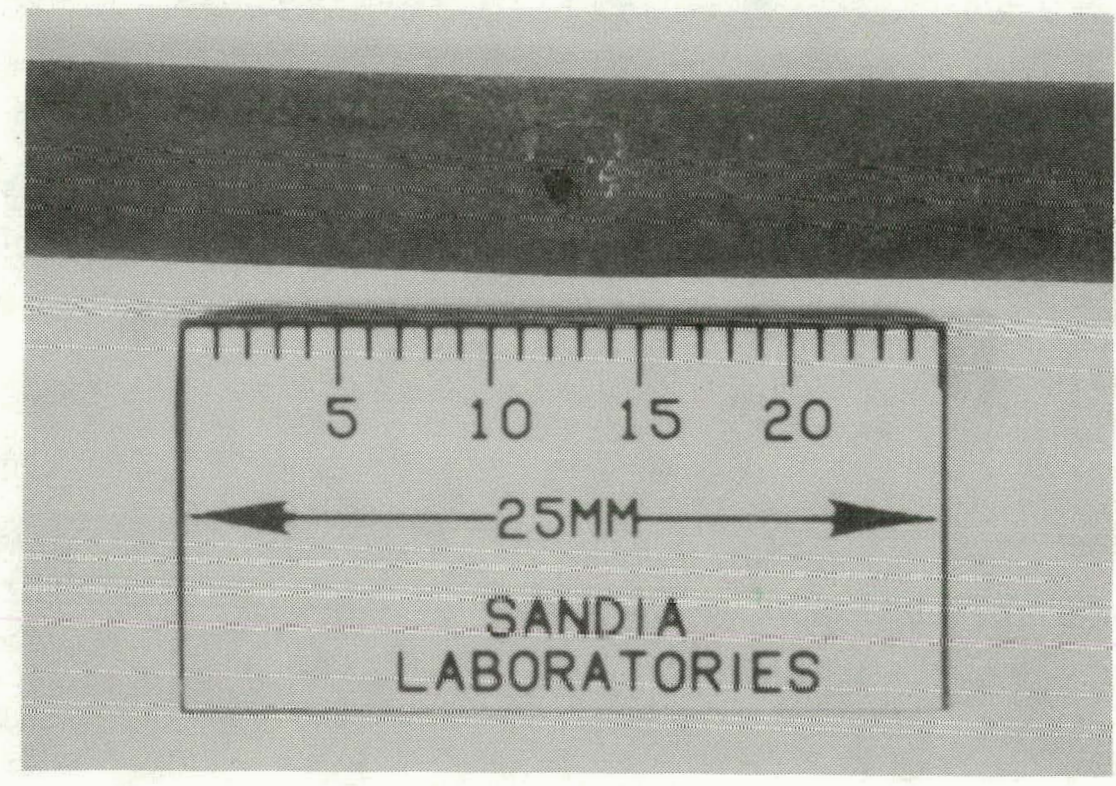

Figure 40. Macrograph of Inconel 600 Tubing

- Sample Line for Air/Diesel DSG - Hole

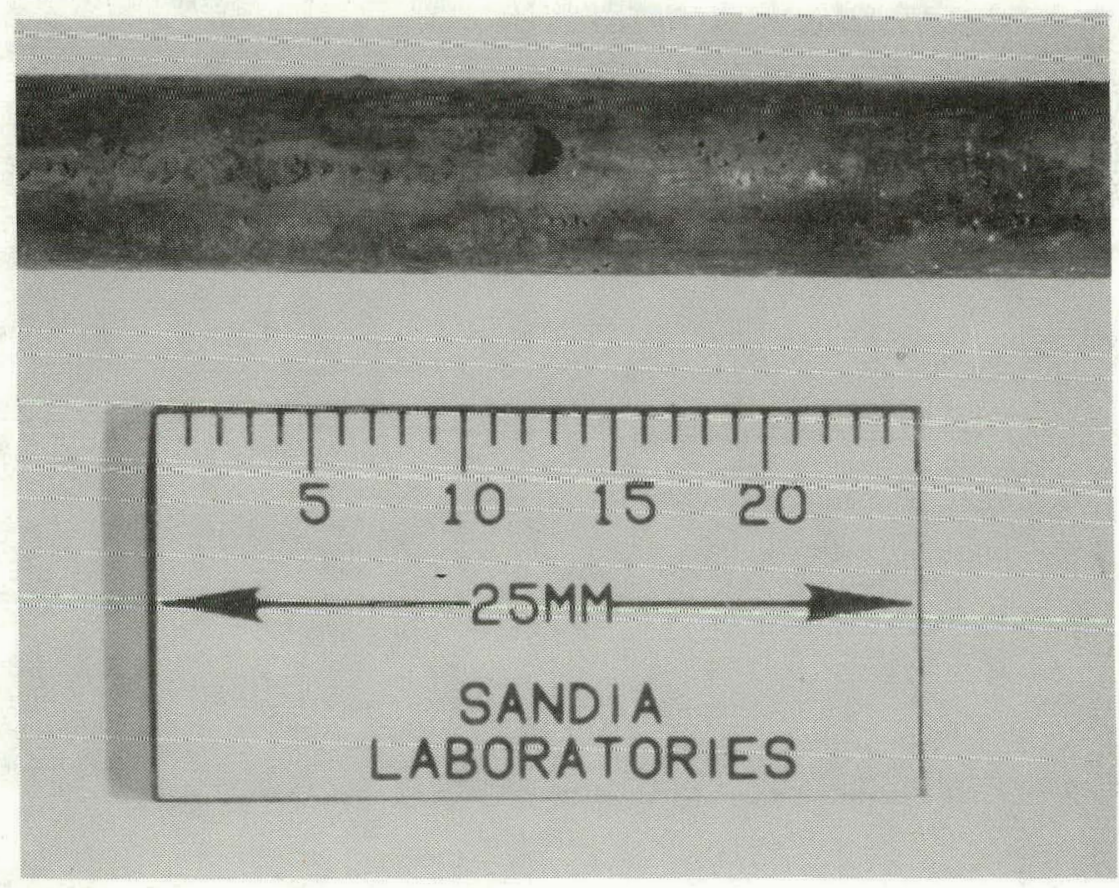

Figure 41. Macrograph of Incone1 600 Tubing

- Annulus Treatment Line for Air/Diese1 DSG - Deep Pit 


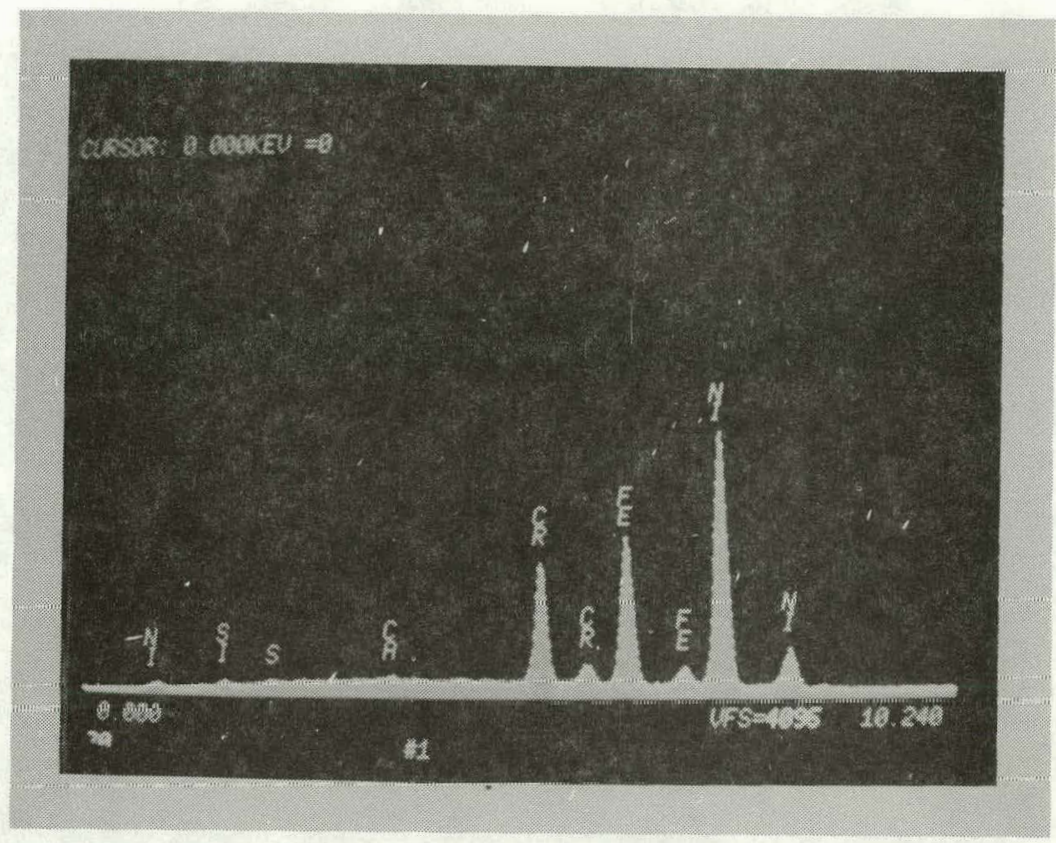

Figure 42. X-Ray Fluorescent Analysis of Inconel 600 Tubing

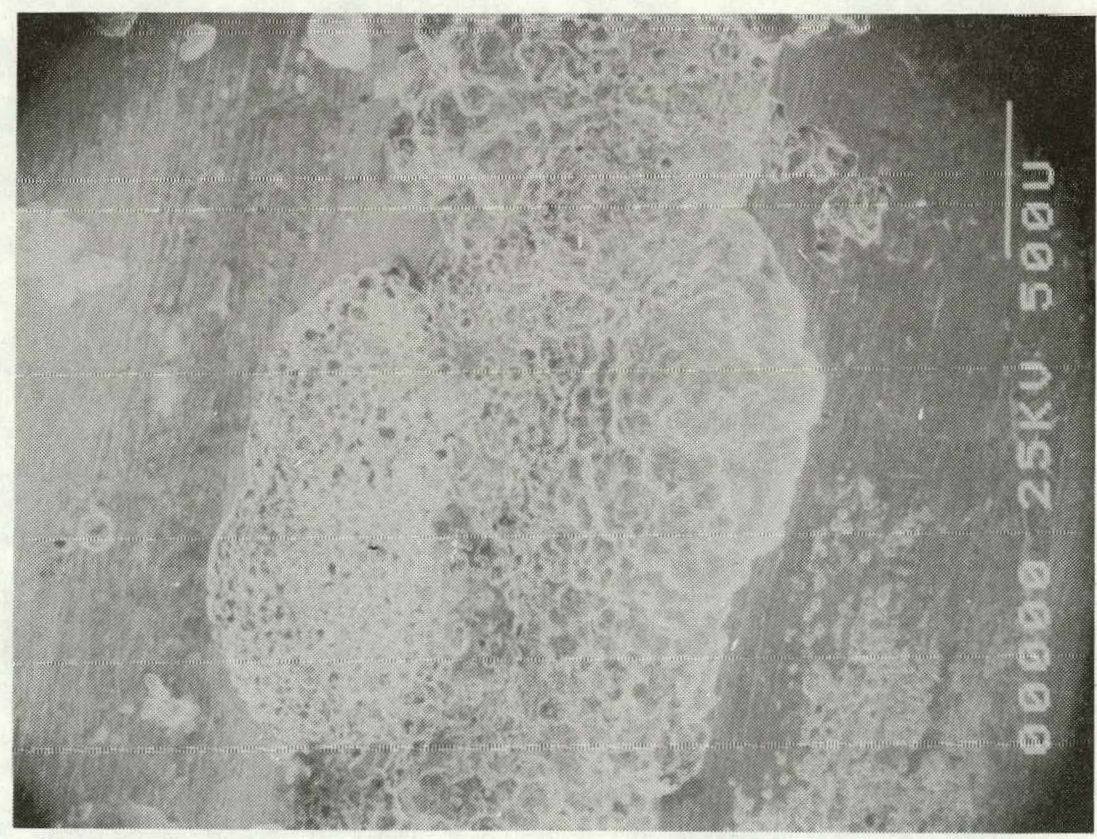

Figure 43. SEM of Pit in Inconel 600 Tubing - 30X 


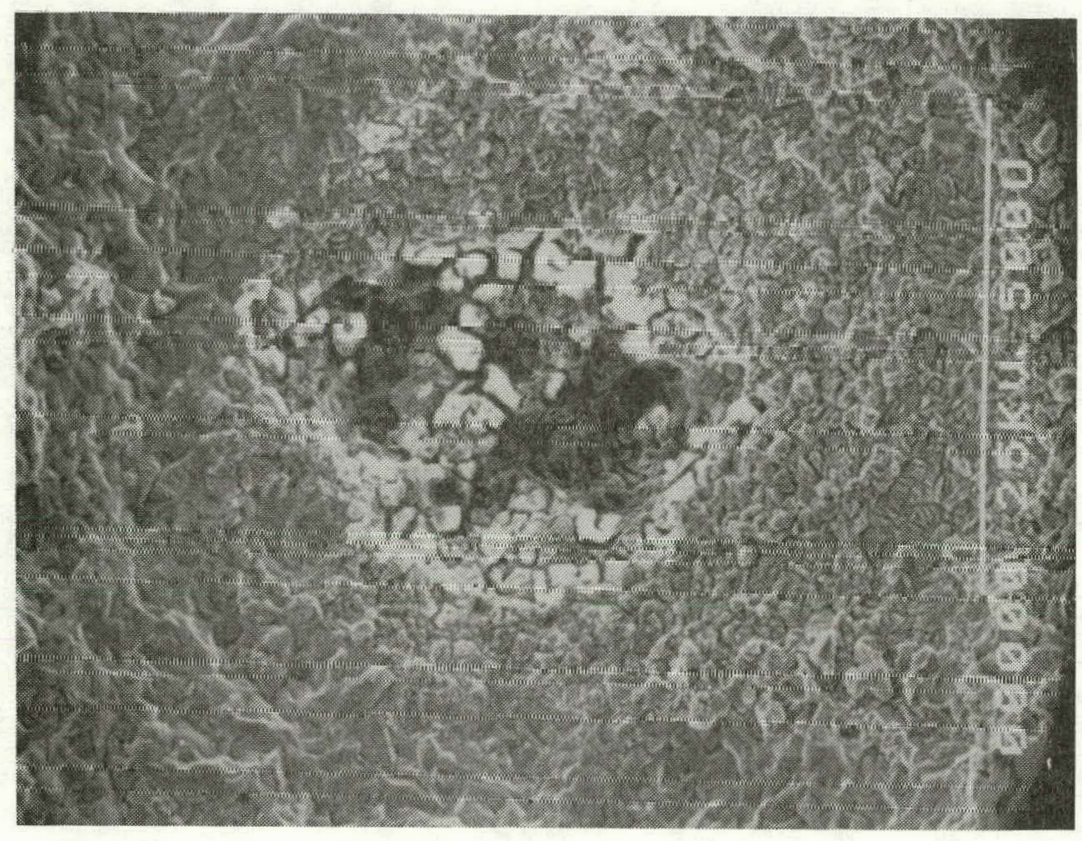

Figure 44. SEM of Pit Showing Intergranular Attack on Inconel 600 Tubing - 100X

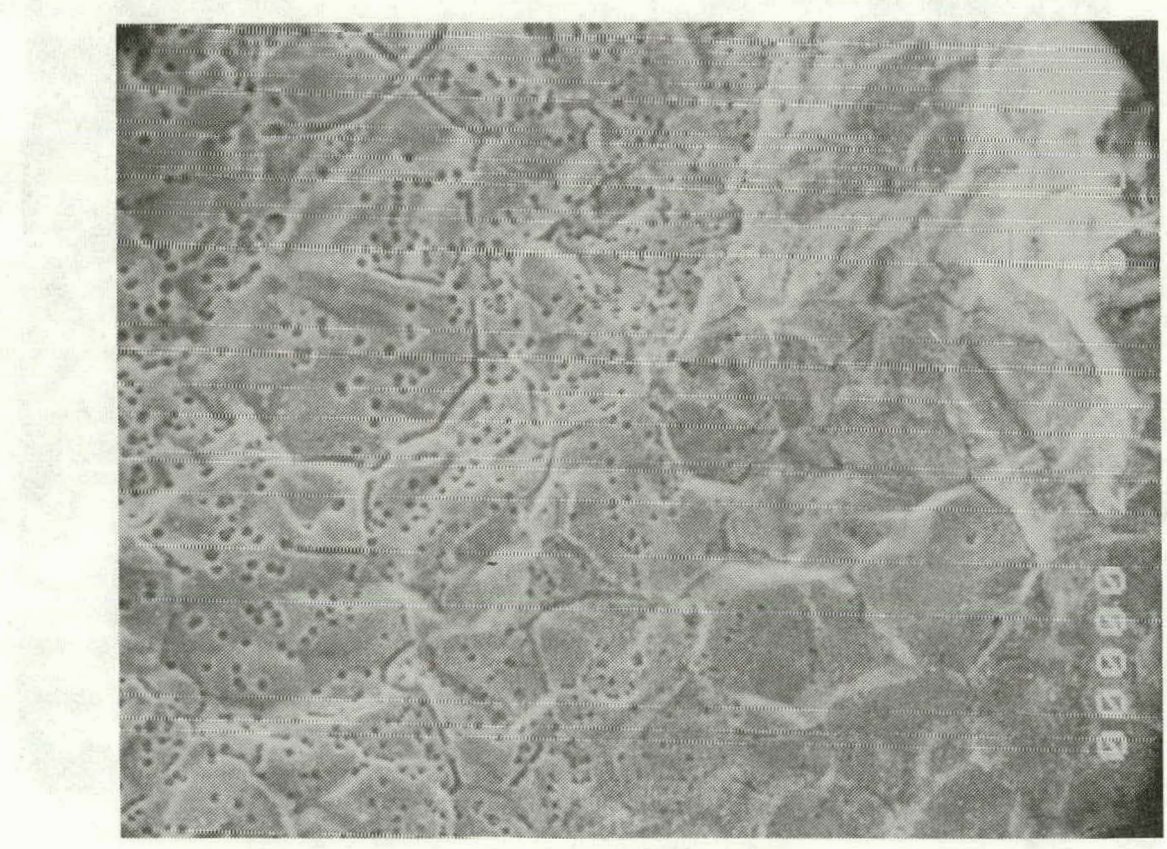

Figure 45. SEM of Intergranular Attack on Inconcl 600 Tubing - 400X 


$\begin{array}{ll}1800 & \text { R. L. Schwoebel } \\ 1810 & \text { R. G. Kepler } \\ 1820 & \text { R. E. Whan } \\ 1830 & \text { M. J. Davis } \\ 1840 & \text { N. J. Magnani } \\ 1841 & \text { R. B. Diegle } \\ 1841 & \text { L. J. Weirick (15) } \\ 1843 & \text { C. J. M. Northrup } \\ 1845 & \text { R. J. Eagan } \\ 1846 & \text { R. K. Quinn } \\ 3141 & \text { L. J. Erickson (5) } \\ 3151 & \text { W. L. Garner (3) } \\ 3154-3 & \text { C. H. Dalin (25) } \\ 8310 & \text { R. W. Rohde } \\ 8312 & \text { D. A. Nissen } \\ 8313 & \text { D. K. Ottesen } \\ 8314 & \text { M. W. Perra } \\ 8315 & \text { L. A. West } \\ 8316 & \text { J. C. Swearengen } \\ 9750 & \text { V. L. Dugan } \\ 9752 & \text { H. M. Dodd } \\ 9753 & \text { D. A. Northrop } \\ 9755 & \text { B. W. Marshal1 } \\ 9755 & \text { D. P. Aeschliman } \\ 9755 & \text { J. B. Moreno } \\ 9755 & \text { J. F. Muir } \\ 9757 & \text { J. K. Linn }\end{array}$




$$
\begin{aligned}
& \text { DO NOT MICPOFILM } \\
& \text { THIS PAGE }
\end{aligned}
$$

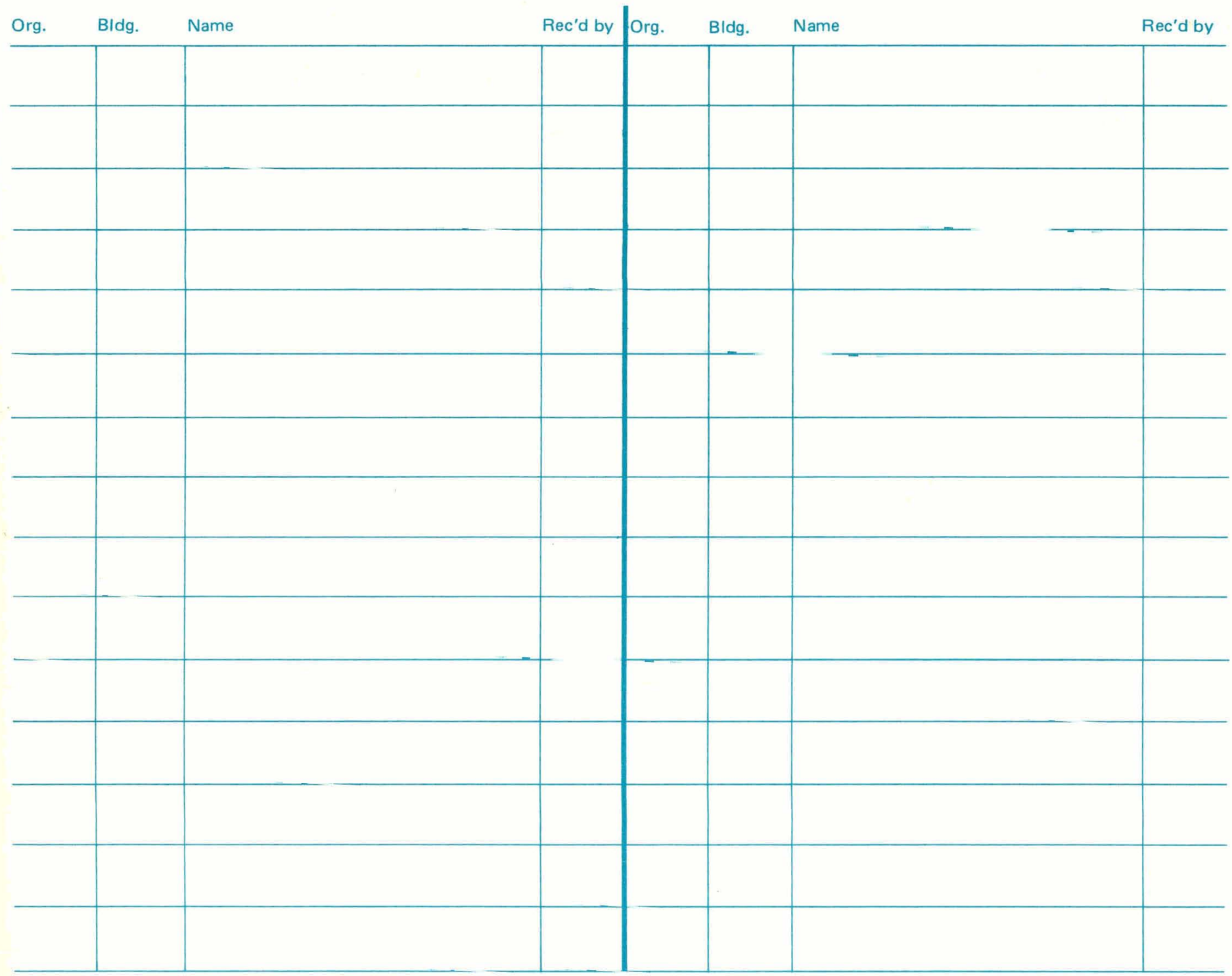

